Provided for non-commercial research and education use. Not for reproduction, distribution or commercial use.

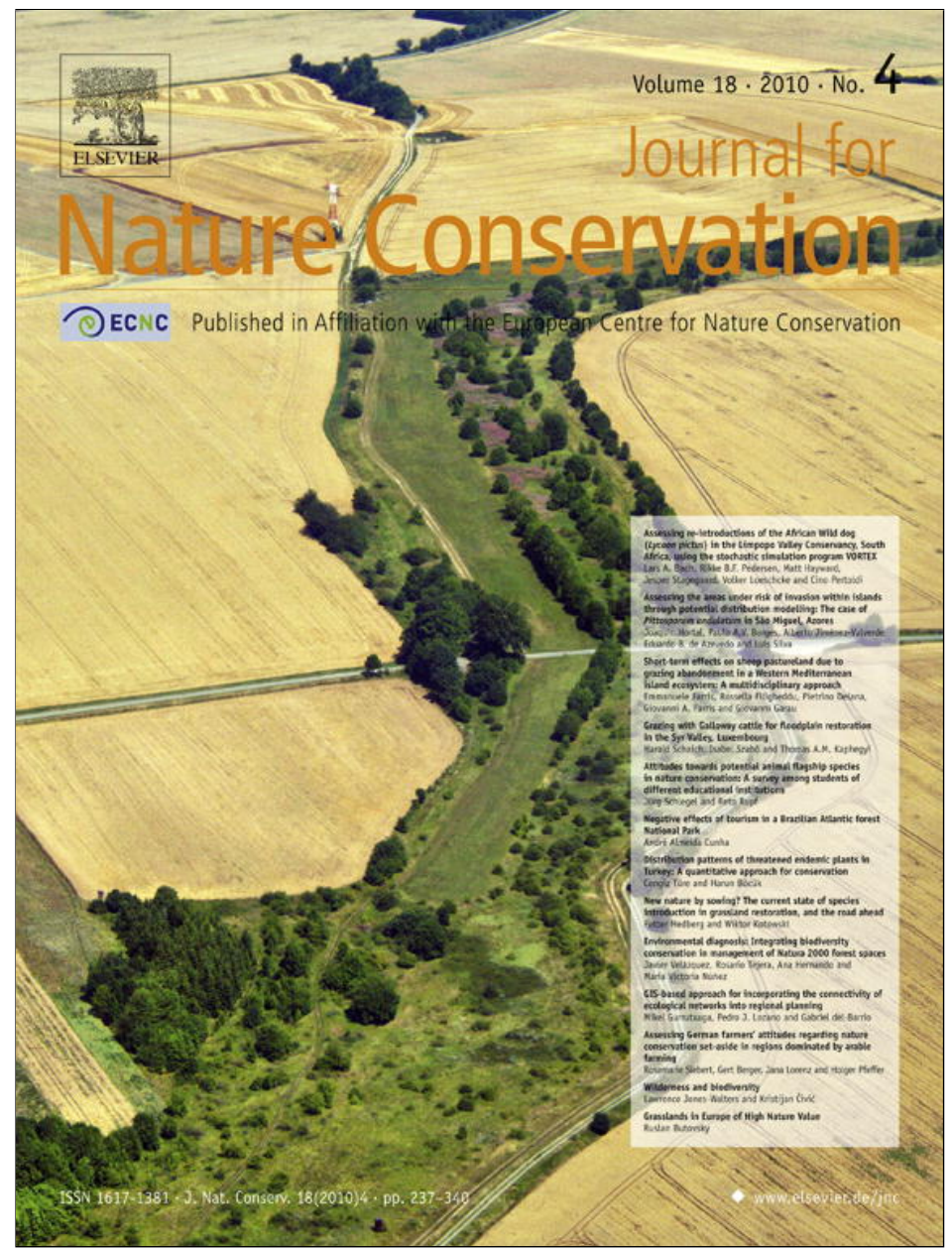

This article appeared in a journal published by Elsevier. The attached copy is furnished to the author for internal non-commercial research and education use, including for instruction at the authors institution and sharing with colleagues.

Other uses, including reproduction and distribution, or selling or licensing copies, or posting to personal, institutional or third party websites are prohibited.

In most cases authors are permitted to post their version of the article (e.g. in Word or Tex form) to their personal website or institutional repository. Authors requiring further information regarding Elsevier's archiving and manuscript policies are encouraged to visit:

http://www.elsevier.com/copyright 


\title{
Assessing the areas under risk of invasion within islands through potential distribution modelling: The case of Pittosporum undulatum in São Miguel, Azores
}

\author{
Joaquín Hortal $^{\mathrm{a}, \mathrm{b}, *}$, Paulo A.V. Borges ${ }^{\mathrm{b}}$, Alberto Jiménez-Valverde ${ }^{\mathrm{c}}$, Eduardo B. de Azevedo ${ }^{\mathrm{d}}$, Luís Silva ${ }^{\mathrm{e}}$ \\ a NERC Centre for Population Biology, Imperial College London, Silwood Park Campus, Ascot, Berkshire, SL5 7PY, UK \\ ${ }^{\mathrm{b}}$ Azorean Biodiversity Group, Universidade dos Açores, CITA-A, Terra-Chã, 9700-851 Angra do Heroísmo, Terceira, Açores, Portugal \\ ${ }^{\mathrm{c}}$ Natural History Museum and Biodiversity Research Center, The University of Kansas, Lawrence, Kansas 66045, USA \\ d CMMG (Centro de Estudos do Clima, Meteorologia e Mudanças Globais), Universidade dos Açores, Dep. de Ciências Agrárias, Terra-Chã, 9700-851 Angra do Heroísmo, Terceira, \\ Açores, Portugal \\ e CIBIO, Centro de Investigação em Biodiversidade e Recursos Genéticos - Pólo Açores, Departamento de Biologia, Universidade dos Açores, Rua da Mãe de Deus, Apartado 1422, \\ 9501-801 Ponta Delgada, Açores
}

\section{A R T I C L E I N F O}

Article history:

Received 5 August 2009

Accepted 9 November 2009

\section{Keywords:}

Invasive species

Species distribution models

Islands

Azorean laurel forest

Conservation

Risk assessment

\begin{abstract}
A B S T R A C T
Non-indigenous plant species have been frequently reported as successful invaders in island environments, changing plant community composition and structure. This is the case of the sweet pittosporum (Pittosporum undulatum), native from Australia, which is one of the most successful plant invaders in the Azores archipelago. Data extracted from recent forestry inventories were used to model and map the potential distribution of $P$. undulatum in São Miguel, the larger island of the Azores. Current distribution of $P$. undulatum is related to climate, altitude and some human activity effects. Further analysis of the areas under risk of invasion showed that protected areas are under potential threat, although only a few native forest remnants seem to be threatened due to future expansion of $P$. undulatum, since the current distribution of these native communities has been reduced due to clearing and competition with invasive plants. We discuss the threats that any further expansion of the species will represent for low-altitude native forests, as well as the utility of species distribution models in the assessment of the areas under risk of invasion.
\end{abstract}

(c) 2009 Elsevier GmbH. All rights reserved.

\section{Introduction}

Biological invasions, i.e. the introduction and spread of organisms from one region to another by human activities, purposefully or accidentally, are one of the main alterations of the biosphere, along with climate change and natural ecosystem destruction (Williamson 1996; Parker et al. 1999; Simberloff 2004). The steady increase in travel and trade activities worldwide has resulted in a high frequency of successful invasions in many ecological systems (Shigesada \& Kawasaki 1997). Biological invasions are thus one of the most important problems faced by island ecosystems, due to the peculiarities of the native island fauna and flora (Simberloff 1995; Ramos 1996; Olesen et al. 2002). A particular case is that of invasive plants, for they can end up excluding native plant species from their original habitats through direct resource competition, a process of biotic

\footnotetext{
* Corresponding author at: NERC Centre for Population Biology, Imperial College London, Silwood Park Campus, Ascot, Berkshire, SL5 7PY, UK.

Tel.: +44 2075942474; fax: +44 1344873173.

E-mail address: j.hortal@imperial.ac.uk (J. Hortal).
}

homogenisation that is also common to animals. Such replacement produces dramatic changes in the functioning of island systems, causing serious problems not only for conservation, but also in forestry, farming, hydrologic cycles and even in human health. Thus, the effects of invasive plants on islands have been extensively studied in many archipelagos (e.g., DeWalt et al. 2004; Daehler 2005; Kingston \& Waldren 2005; Gangoso et al. 2006).

It was thus not surprising that the recent characterisation of the non-indigenous flora of the Azores showed striking numbers of alien plant species. No less than $60 \%$ of the approximately 900 species of vascular plants inhabiting the Azorean archipelago were introduced by human activities, and are now considered as either naturalised or frequently escaped (Silva et al. 2000; Silva 2001; Silva \& Smith 2004, 2006; Borges et al. 2005). In particular, the native vegetation on São Miguel Island is threatened by several aggressive invaders, including Pittosporum undulatum, Hedychium gardnerianum, Gunnera tinctoria and Clethra arborea (Bibby \& Charlton 1991; Silva 2001; Silva \& Smith 2006). As a result, most forest patches are dominated by $P$. undulatum, Acacia melanoxylon and Eucalyptus globulus, along with few individuals 
remaining from former native forests, like Morella faya and Laurus azorica.

Perhaps the most aggressive of these invaders is Pittosporum undulatum (sweet pittosporum). This tree from the Pittosporaceae family is an invader in many tropical and subtropical mountain forests and in warm temperate regions of both hemispheres and many islands (Gleadow \& Ashton 1981; Manders \& Richardson 1992; Goodland \& Healey 1996; Rose 1997a; Rose \& Fairweather 1997; US Forest Service 2007-2008). At the Azores, it was initially introduced as a hedgerow species for the protection of orange tree plantations (Drouet 1866). Although it was cited as being established in the archipelago by the end of the 19th century (Trelease 1897), the sweet pittosporum has been able to colonise a wide range of habitats in all Azorean islands in less than a century (Sjögren 1973; Schaefer 2003). Currently, it is one of the most important threats to native Azorean biota. However, several economical activities are now dependent on $P$. undulatum, namely the production of honey and the cultivation of pineapple in greenhouses in São Miguel Island, where the foliage is used to produce compost.

The aim of this study is to identify the areas under potential threat from the future spread of Pittosporum undulatum in São Miguel. We use data on a recent exhaustive forest inventory, species distribution modelling (SDM) methodologies and logistic regressions to (i) study the current determinants of the distribution of P. undulatum in São Miguel, (ii) map its potential distribution in the island, and (iii) identify the areas of natural vegetation that could be under threat due to future expansion of the invader. To do this, we first use Ecological Niche Factor Analysis (ENFA; see Hirzel et al. $2002,2004)$ to identify areas where the species is not able to live. Then, we use regression analyses to identify the determinants of its presence and abundance, as well as to model its potential distribution. Finally, we evaluate the potential threats for current natural vegetation remnants, using a spatially explicit framework in a GIS environment.

\section{Methods}

Study area

São Miguel is the largest island of the Azores, an archipelago of volcanic origin located in the North Atlantic Ocean, about
$1,500 \mathrm{~km}$ from mainland Europe. The nine Azorean islands span $615 \mathrm{~km}$ along a SE-NW axis, São Miguel is part of the Eastern group together with Santa Maria, the oldest and easternmost island, which is placed $81 \mathrm{~km}$ to the southeast (Fig. 1). São Miguel Island extends along an E-W axis which starts in the old solid mass of Povoação and Nordeste, the oldest of the island (dated about 4 Mys ago), which also holds the highest peak (Pico da Vara, 1,103 m.a.s.l.). The island continues towards the west by a series of connected younger volcanic masses, the westernmost (Sete Cidades) is still active, with the last eruption dated in 1652. Climate is temperate oceanic with a mean annual temperature of $17{ }^{\circ} \mathrm{C}$ at sea level. Relative humidity is high and rainfall is topographically determined, ranging from $1,000 \mathrm{~mm} / \mathrm{yr}$ in the coast to well above $3,000 \mathrm{~mm} / \mathrm{yr}$ in the highest altitudes of the volcanic buildings.

Human settlement in the Azores began in the 15th century. Since then, several activities have altered native plant communities, namely, replacement of the original vegetation cover for cereal crops, pasture and forestry and the introduction of numerous crop, fodder, forest, ornamental and hedgerow plant species (Martins 1993; Silva 2001; Silva \& Smith 2004, 2006).

\section{Data origin}

Data on the distribution and dominance of $P$. undulatum at a $100 \times 100 \mathrm{~m}$ grain size (Fig. 2 and S1) were obtained from the Forestry Department Census (Inventário Forestal da Ilha de São Miguel, Direcção Regional dos Recursos Florestais, Ponta Delgada; http://www.azores.gov.pt/Portal/pt/entidades/sraf-drrf/). Dominance accounts for the role of the species in vegetation formations on an ordinal scale (see below). We assume that this variable is an indirect proxy for the success of the species in the island; the higher the dominance, the stronger the competitive displacement of other species, and therefore the more successful the species has been.

In addition to this, we compiled a comprehensive GIS database of variables which could potentially determine the distribution of $P$. undulatum in São Miguel Island (i.e., geomorphology, climate and human influence). Data were gathered using IDRISI software and data formats (Clark Labs 2004), and included information on 95 variables for each $100 \times 100 \mathrm{~m}$ grid cell on the island, from three categories of maps:

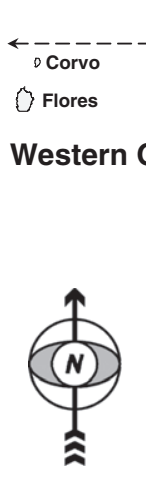

AZORES

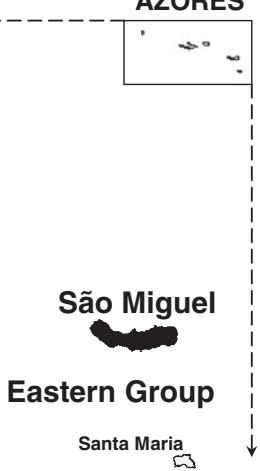

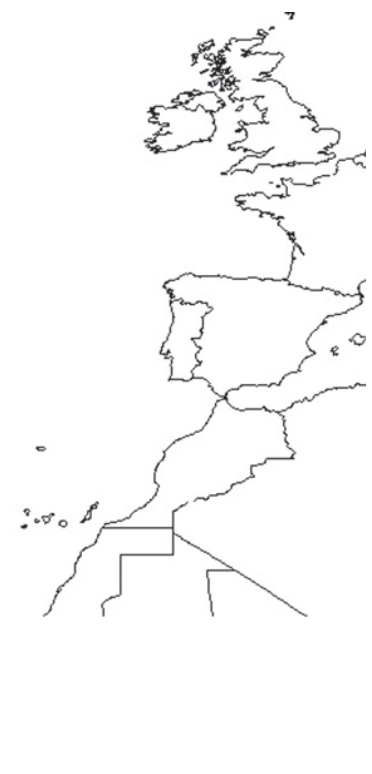

Fig. 1. Location of the Azores in the northern Atlantic, and of São Miguel island within the archipelago. 


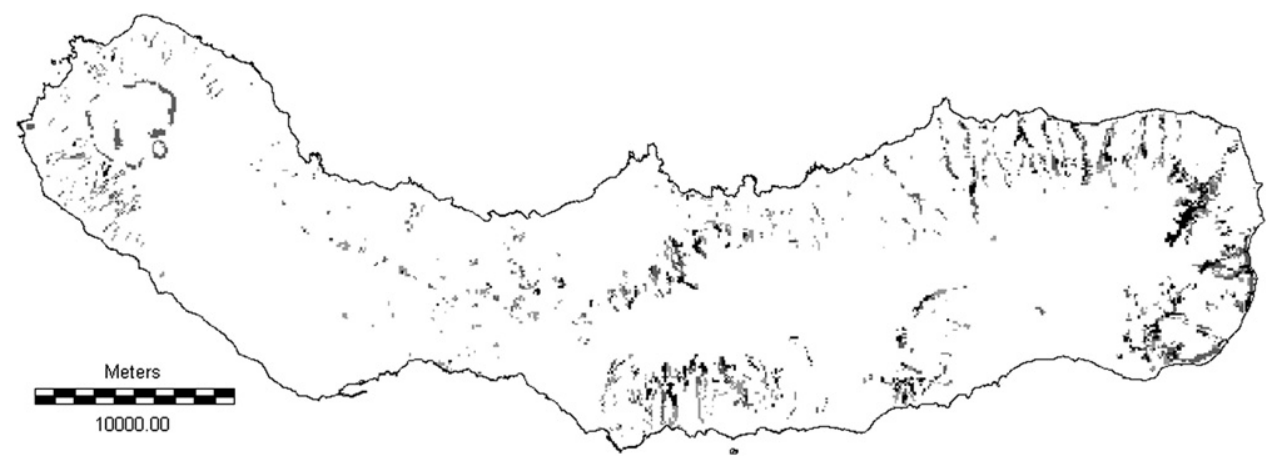

Fig. 2. Current distribution of Pittosporum undulatum in São Miguel Island. Medium grey are the forest patches where the species appears as part of formations dominated by other species. Dark grey are the forest patches where the species is dominant, and Black are those patches where P. undulatum is the unique forest species. See Figure S1 for a colour version.

Geomorphology data. A raster Digital Elevation Model (DEM) was developed by interpolating the altitude curves of the Digital Chart developed by the Cartographic Service of the Portuguese Army (available at http://snig.igeo.pt/). Apart from altitude (ALT), slope and aspect maps were developed from such a map, and aspect was reclassified as degrees to the north (i.e., northing) to obtain a consistent predictor. Additional information about the location of water courses was also obtained from the same Digital Chart; presence of water courses (WC) and distance to the nearest water course (DWC) were used as predictors in the following analyses.

Climate data comes from the CIELO Model (Azevedo et al. 1999), developed to simulate local climate in island environments. CIELO simulates the distribution of climatic variables in an island, in a raster GIS parameterised with a DEM, using data from the synoptic reference of a meteorological station. The grid is oriented following the direction of the circulation of air masses through a specific algorithm. The model consists of two main submodels: 1) relative to the advective component simulation, assumes the Foehn effect to reproduce the dynamic and thermodynamic processes occurring when an air mass moves over an island, enabling the simulation of air temperature and humidity, cloudiness and precipitation; and 2) the sub-model concerns the radiative component as affected by the clouds of orographic origin, and by the shadow produced by the relief. The CIELO model has been calibrated and validated to most Azorean Islands, and is available through CLIMAAT project (CLIMAAT Interreg_IIIB, MAC 2.3/A3; Azevedo 2003; http://www.climaat. angra.uac.pt/). In this work, we have used as predictors the monthly values for precipitation (RAIN), maximum and minimum temperature (TMAX and TMIN), potential evapotranspiration (ET0), Solar Radiation (RS), and maximum and minimum relative humidity (RHMAX and RHMIN) (seven variables $\mathrm{x} 12$ months $=84$ variables). To avoid problems due to the high collinearity among climate variables, and also to reduce them to an easy-to-handle number, we developed a PCA analysis on these variables (Appendix S2). Four Climate Factors (CF) were extracted, accounting for $97.1 \%$ of total variation in these 84 climate variables; CF1 (70.1\% of total variation) identifies a moisturetemperature gradient, including RAIN, TMAX, TMIN and RHMIN; CF2 (17.9\%) does for a limiting energy gradient, including winter and autumn monthly scores for RHO and RS; CF3 (5.49\%) separates hyper-humid areas, including all RHMAX variables; finally, CF4 (3.60\%) holds for a favouring energy gradient, related to summer and spring ETO and RS monthly values (see Appendix $\mathrm{S} 2$ for further information). These four factors (CF1 to CF4) were used as predictors in the modelling process.

Thematic data on the spatial location of human constructions, namely roads, pathways, urban areas, separate buildings, were obtained from the Digital Chart quoted above; distances to the nearest road or pathway (DROAD, a surrogate for accessibility), to the nearest urban area (DURB), to the nearest building (DBUILD, i.e., constructions found either within or outside urban areas), and to the nearest cultivated area (DCUL) were calculated, and were used as a surrogates of human influence on $P$. undulatum patterns at 2002 (the date of publication of the Digital Chart). Additional up-to-date information about the location of Natural Protected Areas and laurel forest remnants (i.e., Natural Forests) was obtained from the Environment Department (Direcção Regional do Ambiente, Horta; http://www.azores.gov.pt/Portal/pt/enti dades/sram-dra/).

\section{Data Analysis}

The concept and application of niche theory in species distribution modelling is currently under debate (see, e.g., Mackey \& Lindenmayer 2001; Soberón \& Peterson 2005; Araújo \& Guisan 2006; Soberón 2007; Austin 2007; Jiménez-Valverde et al. 2008). Therefore, rather than directly applying either the most powerful, the most easy-to-use, or simply the fanciest SDM technique, the decision on the methodological approach used relied upon a reflection about the specific purpose of the analysis.

We aim to evaluate the areas under potential threat from P. undulatum in São Miguel (i.e., the areas that could be invaded by the species). Given that the species has been successful in dispersing throughout the island (see discussion), we assume that there are no significant limits to its dispersal at the scale of the analysis. Therefore, we are interested in modelling the environmental part of its spatial response, assuming that the higher the adequacy of each site for the species, the higher the potential threat to native forest remnants. However, although $P$. undulatum has been successful in colonising São Miguel Island, and soil properties are not a limiting factor for the species in the island (see discussion), its current distribution is not at equilibrium with fine-grain environmental conditions. Other factors, apart from its response to climate variations, have shaped the pattern of territorial occupancy; land-use practices and management (e.g. cattle herding) and dispersal dynamics seem to have restricted the distribution of the species to the remnants shown in Fig. 2. Therefore, although our data contains information about where the sweet pittosporum is able to live, absences are not only placed where the species is unable to establish populations, but also in areas that could be suitable, but the species is not currently present. We thus discard the observed absences for the modelling procedure, because some of them might not reflect the environmental limitations of the species (see Jiménez-Valverde et al. 2008). 
It follows that it is advisable to create data on likely absences that account for the limitations of the species' environmental response and its exclusion from certain areas (Ferrier \& Watson 1997; Zaniewski et al. 2002; Engler et al. 2004; Lobo et al. 2006, 2010; Václavík \& Meentemeyer 2009). Here, likely absences are pseudo-absences (i.e. absence data not coming from surveys) constrained to areas where it is highly unlikely that the species is either present or able to establish populations (i.e., environmental absences sensu Lobo et al. 2010). We used Ecological Niche Factor Analysis (ENFA; Hirzel et al. 2002), a simple SDM technique, to generate these likely absences before modelling the potential distribution of $P$. undulatum. We performed an ENFA analysis with Biomapper software (Hirzel et al. 2004), using all climate variables as predictors and a geometric mean distance algorithm. The results of such analysis provided a first measure of habitat suitability, in a 0 to 100 scale. We considered all grid cells with habitat suitability scores under 10 as absences (see Engler et al. 2004; Jiménez-Valverde et al. 2007). The total number of grid cells with likely absences $(9,693)$ was twice as high as the number of presences $(4,420)$. All these data were used in the subsequent SDM analyses $(\mathrm{N}=15,013)$.

We modelled two different dependent variables, presence/ absence and dominance of the sweet pittosporum. These variables provide two different probability surfaces accounting for the risk of invasion by the species. The first one provides a measure of where the species is able to establish populations (increasing from 0 to 1 ). Dominance describes the pre-eminence of $P$. undulatum stands in the forest canopy and understory strata, and hence could be understood as a proxy of its competitive power. Original scores for such a variable come from a 4-category ordinal variable, and were extracted from the abovementioned Forestry Department Census: 0 (absence, here restricted to the likely absences obtained with ENFA); 1 (present, but not dominant); 2 (dominant in the forest, i.e., providing the main coverage in the canopy stratum); and 3 (extremely dominant, i.e., dominant in both canopy and understory strata). We modelled dominance as an ordinal multinomial variable, to obtain scores ranging from negative values to more than 3 , and assumed that the higher the score of the modelled value, the greater is the competitive power of the species, and thus its capacity of displacing endemic plant formations.

We used General Linear Models (GLM; McCullagh \& Nelder 1989) for both modelling processes, as the ability of these methods to capture species responses to environmental gradients is rooted in a strong theoretical background (Austin et al. 1990; Austin 2002; Maes et al. 2010). Presence/absence data were modelled using logistic regression (logit regression with logarithmic link function), and common multinomial regression was used to model the dominance (assuming normal distribution for the variable and identity as the link function with the predictors). The linear and quadratic equations were evaluated for all continuous predictors. A mixed forward/backward process was used, where variables were entered one by one in the model in a forward regression, and a backward regression is used to eliminate nonsignificant terms after each inclusion (see e.g. Hortal et al. 2001). All calculations were made using STATISTICA (StatSoft Inc 2003). Accuracy in presence/absence model predictions was assessed using a jackknife procedure, a technique which yields relatively unbiased estimates of model performance (Olden et al. 2002). Here, an observation is excluded and the model is parameterised again with the remaining $n-1$ observations to obtain a predicted probability for the excluded observation. This procedure is repeated $n$ times (one per observation), and receiver operating characteristics (ROC) technique is applied, using the area under the curve (AUC) as a measure of overall accuracy (Fielding \& Bell 1997; Pearce \& Ferrier 2000). The evaluation of SDM results using
AUC presents a number of problems (see Lobo et al. 2008), so we also calculated sensitivity and specificity (presences correctly predicted as presences and absences correctly predicted as absences, respectively) using the new jackknife probabilities; as these two accuracy measures depend on a threshold value, above which probabilities are considered as presences, we applied the threshold which minimises the difference between sensitivity and specificity (Jiménez-Valverde \& Lobo 2006; see also Liu et al. 2005, and Thomaes et al. 2008 for an example of this validation protocol). All jackknife computations were performed in $\mathrm{R}$ ( $\mathrm{R}$ Development Core Team 2004).

The dominance model was validated by partitioning the data into 20 data sets, training the model with 19 sets and validating in the remaining set, one in turn. Predictive error (PE) was computed as:

$P E=\frac{A B S[(o b s+1)-(\text { pred }+1)]}{o b s+1} \times 100$

were $o b s$ are the observed scores, and pred are model predictions. Mean Predictive Error (MPE) was averaged among the 20 splits. The Predictive Power (PP) of the model would be an estimate of its accuracy when extrapolated outside of the bounds of the data used, and is just the inverse of MPE (i.e., PP=100 - MPE; see Hortal et al. 2001).

\section{Results}

Climate, altitude and some human effects appear to be affecting both the presence and dominance of $P$. undulatum (Table 1). Interestingly, CF1, altitude and the distances to urban areas and buildings appear as the most important determinants in both cases. Explained deviance was consistently higher for presence than for dominance; whereas in the former the scores of the abovementioned variables were higher than $75 \%$, except for DBUILD (53\%), their explanatory capacity decreased to $42 \%, 45 \%$, $32 \%$ and $27 \%$, respectively in the latter. CF 4 and slope presented much smaller effects, around $6 \%$ and $5 \%$ for presence, and $6 \%$ and $3.5 \%$ for dominance, respectively (Table 1 ). Other variables, such as DWC, also presented minor significant effects, although some of them were also included in the final predictive models (see below).

The model for presences includes CF1, CF2, CF3, CF4, ALT, ASPECT, SLOPE and DWC, whereas the model for dominances includes CF1, CF2, CF4, ASPECT, SLOPE and DWC. Explained deviance was much higher for the presence than for the dominance model ( $88.7 \%$ vs. $58.8 \%)$. The former also showed higher predictive power according to the results of the jackknife procedure; the values of sensitivity and specificity of $97 \%$ and AUC $=0.99$ indicate great discriminatory power (following Swets 1988). The dominance model showed a MPE of $30.81 \%$ and a PP of $69.19 \%$. Both models showed higher explanatory power than explained variability, evidencing the robustness of the variables used.

The areas predicted to be either suitable or unsuitable for Pittosporum undulatum in São Miguel are of lower altitude, precipitations and relative humidity, and of higher temperatures, with more energy inputs during spring and summer (Fig. 3 and Appendix S3). In general, this species is not able to colonise areas over 650 m.a.s.l., with minimum monthly temperatures below $6^{\circ} \mathrm{C}$. When the scores of the models are extrapolated, several natural areas appear to be potentially under threat; the sweet pittosporum could potentially invade territories dominated by native vegetation that are currently under some protection status (e.g. Lagoa do Fogo and Pico da Vara), although predicted dominance scores are low for these areas (see Fig. 4). 
Table 1

GLM results for all explanatory variables included in the analysis, with their respective codes (see text), and the models used for prediction. Deviance and Change in Deviance were calculated through the comparison with a null model (with no explanatory variables) of sweet pittosporum presence (left) and dominance (right). The linear or quadratic functions of each variable were selected when they produced a Change in Deviance significant at a 5\% level. According to $F$ statistics, all explored functions are significant at a 0.05 level (with 10356 d.f., $F=2.999$ provides significance at 0.05 level). Best subset models are the ones used for predictions of pittosporum habitat adequacy; the model for presences includes CF1, CF2, CF3, CF4, ALT, ASPECT, SLOPE and DWC, whereas the model for dominances includes CF1, CF2, CF4, ASPECT, SLOPE and DWC. Dev: Deviance; Ch. Dev: Change in Deviance; \% Dev: Percentage of Deviance explained (i.e., explanatory capacity of the model). Sens: sensitivity (presences correctly predicted); Spec: specificity (absences correctly predicted); AUC, area under the ROC curve. EPM and PP are, respectively, the Mean Prediction Error and the Predictive Power of these functions.

\begin{tabular}{|c|c|c|c|c|c|c|c|c|c|c|c|}
\hline Presence Model & d.f. & Dev & Ch. Dev. & $\boldsymbol{F}$ & \% Dev & Dominance Model & d.f. & Dev & Ch. Dev. & $\boldsymbol{F}$ & \% Dev \\
\hline Null & 10357 & 14128.2 & & & & null model & 10357 & 23740.1 & & & \\
\hline CF1 & 10356 & 3244.2 & 10884.0 & 34743.6 & 77.04 & $\mathrm{CF} 1+\mathrm{CF} 1^{2}$ & 10355 & 13878.7 & 9861.4 & 22075.8 & 41.54 \\
\hline CF2 & 10356 & 13729.4 & 398.8 & 300.8 & 2.82 & CF2 & 10356 & 23379.8 & 360.2 & 478.7 & 1.52 \\
\hline CF3 & 10356 & 14078.6 & 49.6 & 36.5 & 0.35 & CF3 & 10356 & 23719.5 & 20.6 & 27.0 & 0.09 \\
\hline CF4 & 10356 & 13242.3 & 886.0 & 692.9 & 6.27 & $\mathrm{CF} 4+\mathrm{CF} 4^{2}$ & 10355 & 22383.3 & 1356.8 & 1883.2 & 5.72 \\
\hline ALT & 10356 & 3391.3 & 10736.9 & 32786.7 & 76.00 & $\mathrm{ALT}+\mathrm{ALT}^{2}$ & 10355 & 13053.8 & 10686.2 & 25434.0 & 45.01 \\
\hline SLOPE & 10356 & 13376.0 & 752.2 & 582.4 & 5.32 & SLOPE & 10356 & 22911.7 & 828.4 & 1123.3 & 3.49 \\
\hline ASPECT & 10356 & 13590.4 & 537.8 & 409.8 & 3.81 & ASPECT & 10356 & 23214.7 & 525.4 & 703.1 & 2.21 \\
\hline WC & 10356 & 14107.5 & 20.7 & 15.2 & 0.15 & WC & 10356 & 23712.4 & 27.7 & 36.2 & 0.12 \\
\hline DWC & 10356 & 13688.6 & 439.7 & 332.6 & 3.11 & DWC & 10356 & 23638.3 & 101.8 & 133.8 & 0.43 \\
\hline DROAD & 10356 & 13977.6 & 150.6 & 111.6 & 1.07 & DROAD & 10356 & 23552.5 & 187.5 & 247.4 & 0.79 \\
\hline DURB + DURB ${ }^{2}$ & 10355 & 3135.2 & 10993.0 & 36307.7 & 77.81 & DURB + DURB ${ }^{2}$ & 10355 & 16037.2 & 7702.9 & 14923.0 & 32.45 \\
\hline DBUILD & 10356 & 6662.1 & 7466.1 & 11605.8 & 52.85 & DBUILD + DBUILD ${ }^{2}$ & 10355 & 17250.5 & 6489.6 & 11688.1 & 27.34 \\
\hline DCUL & 10356 & 13770.0 & 358.2 & 269.4 & 2.54 & DCUL & 10356 & 23464.8 & 275.3 & 364.5 & 1.16 \\
\hline \multirow{2}{*}{ Best subset } & 10349 & 1598.726 & 12529.5 & 81107 & 88.68 & Best subset & 10351 & 5075.1 & 7241.2 & 14768.9 & 58.79 \\
\hline & Sens $=97 \%$ & \multicolumn{2}{|c|}{ Spec $=97 \%$} & \multicolumn{2}{|c|}{ AUC $=0.99$} & & & \multicolumn{2}{|c|}{$\mathrm{MPE}=30.81$} & \multicolumn{2}{|c|}{$P P=69.19$} \\
\hline
\end{tabular}

\section{Discussion}

By relating the information from a forestry census with GIS environmental data, we have been able to highlight the extent of the threat posed by the invasion of sweet pittosporum for most of the remnants of natural vegetation in São Miguel. According to our results, this invader could be able to establish populations in almost all the areas of the island below 700 m.a.s.l., having the possibility of becoming the dominant and/or the unique forest species in many of these places. These areas are the most affected by human activity, at present and also historically, through the transformation of the natural vegetation into agricultural or forestry land. Given such impact, the potential conservation threat of this invader could seem minimal, because its future spread will happen in areas that have already been highly modified. However, its extreme ability to outcompete the Azorean native forest species makes it also one of the most important (if not the most important) threat for the species inhabiting the very last remnants of the original low-altitude native forests that are now under protection. A dramatic example of this process is Graciosa Island (also in the Azores), where sweet pittosporum is taking over the very last remains of Morella faya-dominated forest. The extent of the threats imposed by such dramatic replacement of the native forest is evidenced by the role played by this invader in the decline of the populations of the only Azorean endemic bird species, the Azorean bullfinch (Priôlo, Phyrrula murina Godman) (Ramos 1996). This species is not able to feed on $P$. undulatum forests because their high density and dense cover limit the growth of the ground and herbaceous plants the bullfinch feeds from (Ramos 1995).

\section{Using species distribution models to assess the level of threat of invasion}

In spite of their wide development and usage in the last two decades, species distribution models present several drawbacks that impose some limits to their use for practical studies. Although they are commonly understood as a tool for the modelling of the environmental niches of species (e.g., Soberón
\& Peterson 2005) their utility for such task is limited (Jiménez-Valverde et al. 2008; Soberón \& Nakamura 2009). On the one hand, most species distributions are not in equilibrium with environment (e.g., Araújo \& Pearson 2005), so bioclimate envelopes might not be able to recover the whole potential response of species to environmental gradients, in spite of their goodness of fit (Jiménez-Valverde et al. 2008). Rather, other factors are shaping the spatial responses of species, and should be taken into account to model such responses (Kearney 2006; Soberón 2007; Lobo 2008; Jiménez-Valverde et al. 2008; Soberón \& Nakamura 2009). This is a key question in the case of invaders, as they may not have had time to occupy all suitable places in the new territory (Peterson 2005), hence providing additional uncertainty to the analyses on their potential distributions (e.g., Hartley et al. 2006). On the other hand, the available data on the distribution of species is often not good enough to ensure the reliability of the results of the modelling process, being plagued by spatial biases, hence providing incomplete descriptions of the spatial and environmental responses of species (Lobo et al. 2007; Lobo 2008; Hortal et al. 2007, 2008). This can be especially true in the case of invaders, because often only occurrence data from the invaded area are used in the modelling process (Mau-Crimmins et al. 2006).

Given these drawbacks, any implementation of species distribution models should be based on a proper acknowledgement of their limitations for the question at hand, and the development of a protocol adequate to solve such a question with the available information. In our case, data quality is not a concern, because we use a complete inventory of the presence and dominance of the sweet pittosporum in São Miguel to model its distribution. The likely lack of equilibrium with environment of the distribution of the species is partly acknowledged by our choice of pseudoabsence data well outside of the environmental domain currently occupied by the species, as recommended by Jiménez-Valverde et al. (2008), Lobo et al. (2010), and Václavík and Meentemeyer (2009) for invasive species. The habitat suitability description obtained here would be shown to be an underestimation if the species is able to colonise in the future the remaining high-altitude areas that are currently free from 
a
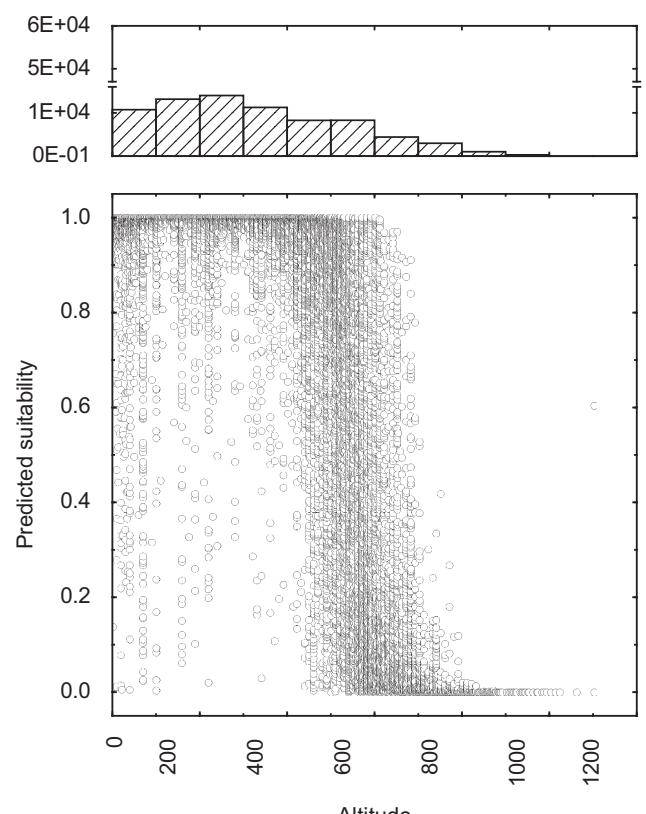
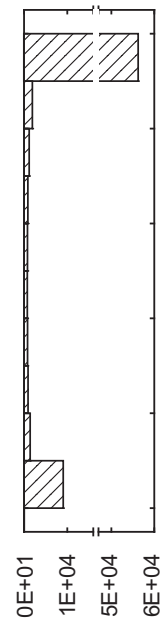

b
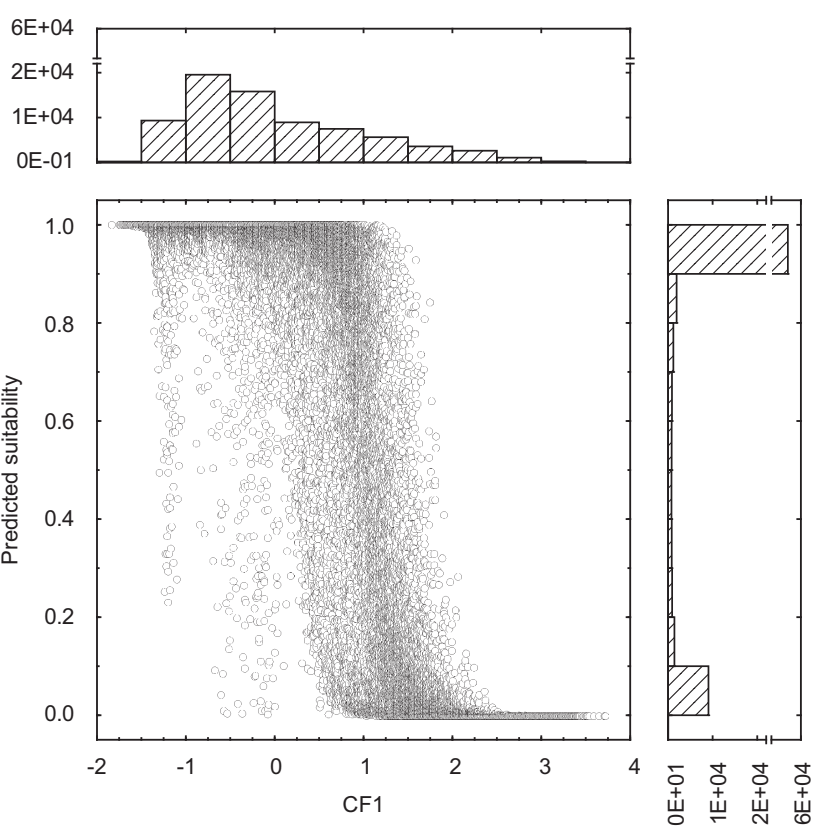

C
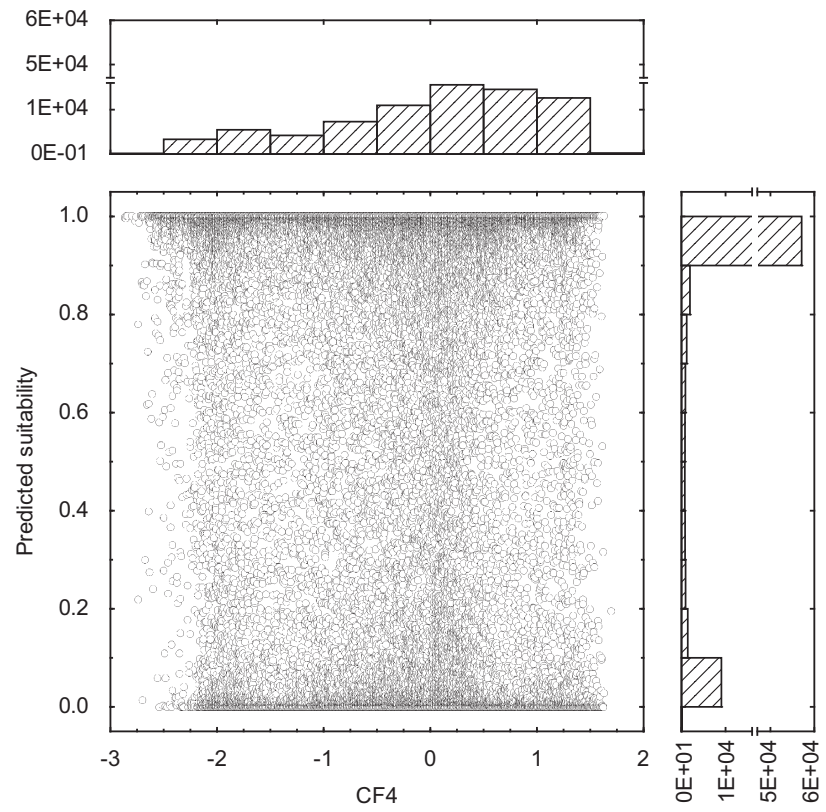

Fig. 3. Relationships between the suitability for the establishment of Pittosporum undulatum, as predicted by our models (see Table 1 ), and the three most relevant environmental predictors: (a) altitude; and the Climatic Factors; (b) CF1, a moisture-temperature gradient (increasingly wetter and colder conditions in the positive values); and (c) CF4, describing the energy input during the growing season (increasing evapotranspiration and solar radiation during spring and summer in the positive values) (see Appendix S2). Suitability varies from 0 (completely unsuitable) to 1 (perfectly suitable). Due to the sheer number of data points, the scatterplots show their density and the histograms their frequency.

invasion. However, given the time since $P$. undulatum established in the island and its rate of invasion (see below), we believe that this is quite unlikely, and hence the eventual changes in our habitat suitability maps would be minimal. In fact, disequilibrium is unlikely to be happening in our case as (i) dispersal capacity of $P$. undulatum within the island is virtually unlimited thanks to blackbirds (see below), and (ii) the species has not been sighted above 800 m.a.s.l. neither on any island of the Azores (Schaefer 2003) nor at the Canary Islands (Weber 2003). Also, the humpshaped relationship of dominance with the first climatic factor and altitude (Table 1 ) evidences that the climatic optimum for the species is presently within the range of conditions found in the island (see also Fig. 3), hence providing indirect support to the idea of the models being developed with an adequate description of the pittosporum's environmental response.

Determinants of current distribution and abundance of sweet pittosporum

The sweet pittosporum in São Miguel is limited by the most important climatic gradient on the island. The steep topography 

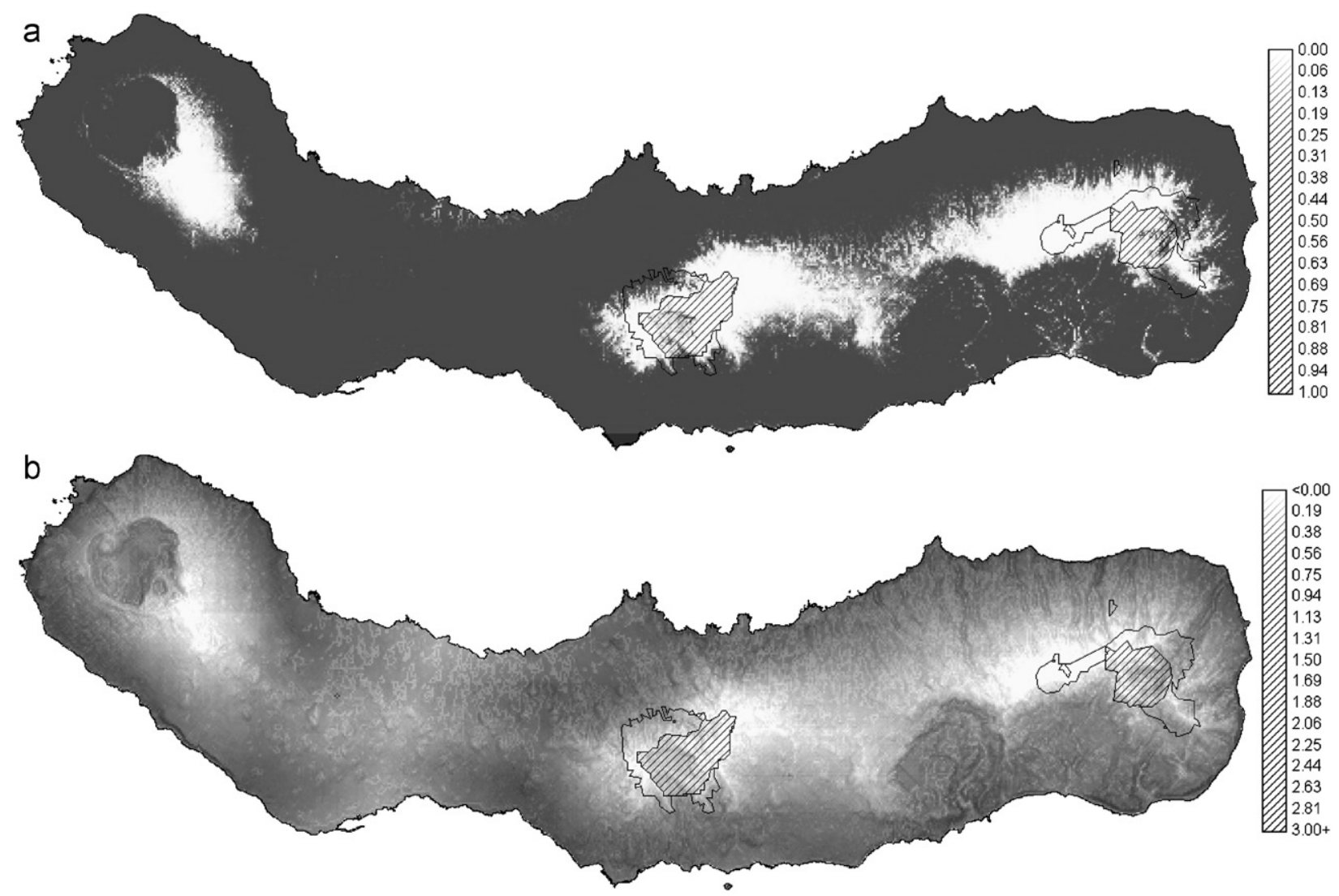

Fig. 4. Predictive maps of Pittosporum undulatum potential distribution (up) and potential dominance (down) in São Miguel Island. Dark grey are maximum scores (1 for presence and 3 or more for dominance), and white are minimums ( 0 for presence and 0 or less for dominance). The current location of Natural Protected Areas (outlined) and the distribution of the remaining natural forests (diagonal lines) are also shown.

causes a striking altitudinal gradient (described by our first climatic factor), where small increases in elevation are followed by important declines in temperature and increases in precipitation and humidity. P. undulatum seems unable to live in the colder and much more humid altitudes of the old volcanic buildings of Sete Cidades in the west, Fogo in the centre of the island, and Furnas and Pico da Vara in the east, and the high altitudes of the Achadas that connect the latter two. According to previous results (Silva 2001; Silva \& Smith 2006), the invasion by P. undulatum mainly affects plant communities from 100 up to $600 \mathrm{~m}$ of altitude, which is consistent with the earlier observations of Sjögren (1973). Therefore, it can be assumed that its distribution is limited by environmental factors that vary with altitude, namely low temperatures and increased exposure to the prevailing winds at higher altitudes (Dias 1996; Goodland \& Healey 1996). In accordance with this, in situ observations showed that fruit production decreases drastically with altitude, particularly above $450 \mathrm{~m}$ (L.S., unpublished data).

The optimum conditions for the species, however, are not placed in the warmest and less humid areas of the island. Rather, its climatic optimum seems to be located at mid-altitudes, as evidenced by the hump-shaped relationship identified by the dominance model (see also Figs. 3a and 3b). In fact, $P$. undulatum is an invader in tropical and subtropical mountain forests, in warm temperate regions of the Northern Hemisphere, in many islands of the Atlantic and Pacific oceans, and in South Africa (Gleadow \& Ashton 1981; Manders \& Richardson 1992; Goodland \& Healey 1996). Indeed, P. undulatum has also invaded plant communities in its native country, establishing successful populations in a wide range of habitats of mild, humid and sub-humid climates in the south of Australia (Gleadow \& Ashton 1981; Rose 1997a; Rose \& Fairweather 1997). It is thus not surprising that $P$. undulatum has become so widespread in the Azores, a typical oceanic archipelago composed of islands with fairly mild and humid climate.

It is now widely accepted that the majority of biological invasions are deliberately and/or accidentally related to human activity, and the invasion process is usually initiated in habitats transformed by human activities (e.g., Cronk \& Fuller 1995; Goodland \& Healey 1996; Rose \& Fairweather 1997; Silva \& Smith 2004). Our results evidence a high spatial relationship with the distance to inhabited areas, the species being most dominant at intermediate distances to buildings and/or urban areas. This could be either the reflection of a true preference for moderately humanised environments within the island, or just a spurious relation due to the spatial location of the first introductions of the species. On the one hand, the land placed near urban areas in São Miguel has been typically used for cultivations of vegetables and corn for domestic consumption. Thus, these areas were regularly cleared, preventing the development of $P$. undulatum forests. On the other hand, the sweet pittosporum was first used during the $19^{\text {th }}$ Century to create living fences around fruit orchards (mainly orange trees) to protect them from strong winds. During the implantation of fruit production for the exportation to Europe and North America, the areas devoted to orchards were placed relatively near (but not next) to urban nuclei. These exploitations (called 'quintas') typically consisted of a large house surrounded by orchards, which could be a cause for the linear correlation with the distance to buildings in the presence model. Whether a direct or indirect by-product of the human use of the islands (or both), 
currently sweet pittosporum shows a clear association with disturbed shrub and forest environments in all Azorean islands.

The relatively small area of most Azorean islands combined with a significant alteration of habitats and favourable climatic conditions might have also been a decisive factor in the rapid and successful P. undulatum invasion (Goodland \& Healey 1996; Rose \& Fairweather 1997; Sanford et al. 2003). In the same way as other invaders take advantage of ecosystem alteration and disturbance (Ogden et al. 2003; Rouget et al. 2003; Shiferaw et al. 2004; Lake \& Leishman 2004), the invasion by $P$. undulatum in the Azores may have been facilitated by disturbance of the native woody vegetation, especially where the cleared areas were abandoned to colonisation by introduced species. During the first phase of human settlement in the Azores, the felling of native woody vegetation for timber and fuel may have opened gaps suitable for invasion by P. undulatum. Either this activity or its wide usage for living fences may have provided the initial impetus for the rapid spread of P.undulatum. This process was later enhanced by the clearance of native vegetation for the installation of agricultural crops. When these cultivations were abandoned, the secondary vegetation has always become dominated by $P$. undulatum. Natural disturbance may also have contributed to this process, since storms and landslides are common events in the islands.

Although disturbance can enhance the invasion process, nonindigenous species are also able to invade intact habitats in many regions of the world (Sanford et al. 2003), including the Azores (Silva \& Smith 2004). Several areas of native vegetation have been invaded by $P$. undulatum at the archipelago, particularly at higher elevations and in very steep terrain. Given that most of these areas have been safe from human intervention due to their inaccessibility, the extreme success of this species can not be explained by human disturbance alone. Dispersal is a crucial stage of the invasion process (Hastings et al. 2005; Facon et al. 2006). Sweet pittosporum found little obstacles to dispersal, since both pollinators and seed dispersers were also present on the time of its introduction. In fact, current honey production at the Azores is based on Apis mellifera and $P$. undulatum flowers, and beehives are placed near wooded areas where $P$. undulatum is common. Also, the dispersal of the invaders with highly nutritive seeds is widely facilitated by frugivorous species (Buckley et al. 2006). Similar to other regions of the world, in the Azores P. undulatum seeds are dispersed by a local subspecies of blackbird, Turdus merula azorensis (Goodland \& Healey 1996; Rose 1997a). Germination essays showed that $P$. undulatum seeds kept their viability after passage through the digestive tract of the bird (L.S., unpublished data).

It should also be stressed that sweet pittosporum occurs in a wide variety of habitats, and soil properties do not seem to be a limiting factor for its establishment, at least at the Azores. In sheltered gullies $P$. undulatum may occur on skeletal soils, and on some coastal sites it appears on bluffs and cliffs within range of severe salt spray or on relatively dry hind dunes (Gleadow \& Ashton 1981). At the Azores, $P$. undulatum is frequent in coastal areas and where Morella faya is recolonising, with the exception of areas that are extremely exposed, affected by salt spray, or subject to hydric stress (Dias 1996; H. Schaefer pers. comm.). In fact, it occurs on very shallow soils in coastal scrub and lava flows, especially where stone walls built to protect orchards and vineyards provide shelter from direct salt spray and wind. The only coastal areas free of its invasion to date are those of intense wind exposure, which at the Azores are dominated by Erica azorica or Arundo donax. P. undulatum is also commonly found forming mixed stands with other non-indigenous trees (Eucalyptus and Acacia), where it ranges from understorey to dominant species. This reflects its association with similar species in its native range where it is one of the most abundant understorey species in different types of Eucalyptus forests. P. undulatum occurs sporadically in notophyllous vine forests, being more frequent on their margins in tall open forests (Gleadow \& Ashton 1981; Goodland \& Healey 1996). It is also present in microphyllous vine forests, especially those in dryer gullies, as well as in wet and dry sclerophyllous forests. This is in agreement with the types of vegetation invaded in the Azores, namely the endemic scrub and the laurel forest, where the main species are sclerophyllous and microphyllous.

\section{Controlling a threat to natural vegetation}

The risk assessment of invasive species for the Pacific Islands catalogues Pittosporum undulatum as being a 'high risk' invader, being a threat to mesic forests (US Forest Service 2007-2008). Such status could easily be extrapolated to the Azores, where it is one of the plants with the highest impact on the vegetation (Sjögren 1973). In this archipelago, sweet pittosporum is already very frequent and abundant in Morella faya scrub and in coastal woods, even on the remote coasts of Corvo, Flores, São Jorge, Graciosa and Pico (Dias 1996; Schaefer 2003). When this invasive species establishes, it is often able to overgrow the native vegetation by shading the indigenous species, forming pure stands particularly in sheltered areas (Gleadow \& Ashton 1981; Dias 1996; Goodland \& Healey 1996; Rose \& Fairweather 1997; Silva 2001). According to a recent evaluation of the Top 100 invasive species in Macaronesia, sweet pittosporum is considered invasive also in Madeira and the Canary islands, and ranked 8th in a total of 195 evaluated species (Silva et al. 2008). In the Azores, $M$. faya has been largely replaced by $P$. undulatum (Palhinha et al. 1942; Palhinha 1944; Machado 1946; Ricardo et al. 1977; Schaefer 2003), altering the natural transition between the native plant communities common between 300 and $600 \mathrm{~m}$ of altitude (Sjögren 1973).

It is important to stress that the results of our study are maps of the areas under threat of invasion within São Miguel according to the environmental preferences of the invader, with some associated uncertainty. Many other factors determine the spread of the species and thus the areas potentially under threat, such as land use (agriculture, forestry, conservation), the implementation (or rather the absence) of conservation measures, and the management options directed towards the areas already invaded by sweet pittosporum in the Azores. In fact, sweet pittosporum is already the dominant woody species in the Azores. From a total woodland cover of 62,982 ha in $2007,33 \%$ was covered by sweet pittosporum, and $31 \%$ of natural vegetation (SRAF 2007). From the remaining area, only $18 \%$ is occupied by the Japanese cedar Cryptomeria japonica, the backbone of the local industrial wood segment. Less important are eucalyptus (6\%) and other species (12\%) (SRAF 2007). The importance and virulence of this threat is such that the implementation of management actions to stop sweet pittosporum spread in the Azores, giving a sustainable use to the vast areas already used by this aggressive invader, should be a priority for both the Azorean regional government and the European Commission, within the Natura 2000 conservation scheme.

Many control measures have been evaluated and used against this invader (Rose 1997b; Silva et al. 1999). Management will demand coordination at the regional level, with selective control, restoration of the invaded communities, and economic utilisation where advisable (Goodland \& Healey 1996). Since this species is widely used for hedgerows in the Azores, and is presently sold at plant nurseries, its future control will be dependent on the availability of native plant species to progressively replace it, namely $M$. faya that was widely used for this purpose in the past. However, in order to sustainably replace $P$. undulatum an integrated strategy should be followed, including replacement of 
hedgerows, removal at priority sites for conservation and progressive substitution in mixed forest. Meanwhile, the removal of woody plant invasive alien species from affected areas is a continuous and intensive effort, with significant and recurring costs derived from high landfill fees and limited availability of space. Finding alternatives to generate an economic return for the resulting biomass would greatly reduce management and control costs, thus ensuring the continuity of such effort. Composting is not a viable option within the general context of the Azores, where there is a lack of significant demand for such service. The only exception is São Miguel Island, where $P$. undulatum foliage is used to produce compost for pineapple plantations, although at a relatively small scale. Rather, sweet pittosporum biomass could be used as a renewable source of biofuel and/or an alternative food for cattle in the winter. We believe that energetic valorisation can constitute a viable alternative for the results of clearing sweet pittosporum stands. A combination of the generalisation of this use for wood material and of leaves and young branches as winter food supplements for cattle, might eventually allow the progressive replacement of $P$. undulatum by Macaronesian species (e.g. M. faya, Persea indica), with a positive impact on local biodiversity.

Thus, as a global strategy for the sustainable management of $P$. undulatum invasion in the Azores, we suggest: (i) the implementation of regional legislation declaring it as a noxious weed and forbidding its commercialisation by plant nurseries; (ii) its progressive replacement by native and other non-invasive species in hedgerows; (iii) the control of $P$. undulatum at priority conservation sites below 650 m.a.s.l., accompanied by planting of native species; and (iv) a phased diversification of the Azorean forestry resources, beginning with the removal of $P$. undulatum and other woody plant invaders, using the biomass for energy production to at least partly cost control measures, and its progressive replacement by native and non-invasive woody species for timber production and other uses. This would allow control of $P$. undulatum while stimulating the diversification of forestry resources, eventually contributing to an increase in the area dedicated to sustainable production forest in the Azores.

In addition to these eradication and control efforts, a fifth program for the continuous monitoring of the areas under risk that have not been invaded yet should be implemented. Also, and given the uncertainty associated to our results, (vi) the protected areas predicted to be unsuitable should also be monitored. The low probability of invasion may lead to specific monitoring programs in these areas being discarded, especially above 650 m.a.s.l. or where minimum temperatures remain below $6^{\circ} \mathrm{C}$ during several months throughout the year (see Fig. 3 and Appendix S3). Rather, we recommend that in these areas the sweet pittosporum is only included in general assessments of the conservation status of the native forests.

To summarise, our results show that $P$. undulatum is a major problem for the management and preservation of natural habitats in the Azores, similar to other areas where it has been introduced. Here we suggest that the decision on where and how to develop control activities needs to be based on both the invasion threat maps generated here (based in species distribution modelling), but also on good empirical data such as the information already available on the Azorean Biodiversity Database (available at http://www.azoresbioportal.angra.uac.pt). Although it is true that the predictions show that the areas under threat of invasion occupy most of the island, such information allows users to determine those locations where the remaining native communities are in need of specific conservation efforts to minimise the impact of this invader. Nevertheless, our work shows how species distribution models can be implemented within a proper risk assessment framework, providing useful information for the control of invasive species at the local scale.

\section{Acknowledgements}

We are indebted to Nuno Cordeiro for his work on the initial stages of this project. We also thank Núria Roura and two anonymous referees for their critical review of the manuscript, Hanno Schaefer for his comments, and the Direcção Regional dos Recursos Florestais and the Direcção Regional do Ambiente of the Governo Regional dos Açores for providing access to GIS data on the distribution and dominance of Pittosporum undulatum and on the location of roads, Natural Areas and forest remnants. Climate data were obtained from Project CLIMAAT, PIC - INTERREG_3B (MAC 2.3/A3). JH was supported by the Portuguese FCT BPD/ 20809/2004 grant and by the UK Natural Environment Research Council, AJ-V by the Spanish MEC postdoctoral fellowship EX2007-0381, and PB by a science management grant from CITA-A, the DRCT projects M2.1.2/I/017/2007 and M.2.1.2/I/003/2008, and the EU INTERREGIII B projects "ATLÂNTICO" (2004-2006) and BIONATURA (2006-2008).

\section{Appendix A. Supplementary material}

Supplementary data associated with this article can be found in the online version at doi:10.1016/j.jnc.2009.11.002.

\section{References}

Araújo, M. B., \& Guisan, A. (2006). Five (or so) challenges for species distribution modelling. Journal of Biogeography, 33, 1677-1688.

Araújo, M. B., \& Pearson, R. G. (2005). Equilibrium of species' distributions with climate. Ecography, 28, 693-695.

Austin, M. (2007). Species distribution models and ecological theory: A critical assessment and some possible new approaches. Ecological Modelling, 200, $1-19$.

Austin, M. P. (2002). Spatial prediction of species distribution: An interface between ecological theory and statistical modelling. Ecological Modelling, 157, $101-118$.

Austin, M. P., Nicholls, A. O., \& Margules, C. R. (1990). Measurement of the realized qualitative niche: environmental niches of five Eucalyptus species. Ecological Monographs, 60, 161-177.

Azevedo, E. B. (2003). Projecto CLIMAAT - Clima e Meteorologia dos Arquipélagos Atlanticos. PIC Interreg_IIIB - Mac 2, 3/A3.

Azevedo, E. B., Pereira, L. S., \& Itier, B. (1999). Modelling the local climate in island environments: Water balance applications. Agricultural Water Management, 40, 393-403.

Bibby, C. J., \& Charlton, T. D. (1991). Observations on the São Miguel bullfinch. Aç oreana, 7, 297-304.

Borges, P.A.V., Cunha, R., Gabriel, R., MArtins, A.F., Silva, L., Vieira, V.et al., (2005). Description of the terrestrial Azorean biodiversity. In P.A.V. Borges, R. Cunha, R. Gabriel, A.F. Martins, L. Silva, \& V. Vieira (Eds.), A list of the terrestrial fauna (Mollusca and Arthropoda) and flora (Bryophyta, Pteridophyta and Spermatophyta) from the Azores (pp. 21-68). Horta, Angra do Heroísmo and Ponta Delgada: Direcção Regional do Ambiente and Universidade dos Açores.

Buckley, Y. M., Anderson, S., Catterall, C. P., Corlett, R. T., Engel, T., \& Gosper, C. R., et al. (2006). Management of plant invasions mediated by frugivore interactions. Journal of Applied Ecology, 43, 848-857.

Clark Labs, C. R. (2004). Idrisi Kilimanjaro version 14.02. GIS software package. Worcester, MA: Clark Labs, Clark University.

Cronk, C. B., \& Fuller, J. L. (1995). Plant invaders. London: Chapman \& Hall.

Daehler, C. C. (2005). Upper-montane plant invasions in the Hawaiian Islands: Patterns and opportunities. Perspectives in Plant Ecology, Evolution \& Systematics, 7, 203-216.

DeWalt, S. J., Denslow, J. S., \& Ickes, K. (2004). Natural-enemy release facilitates habitat expansion of the invasive tropical shrub. Clidemia hirta. Ecology, 85, 471-483.

Dias, E. (1996) Vegetação Natural dos Açores: Ecologia e Sintaxonomia das Florestas Naturais. Ph.D. Thesis, Universidade dos Açores, Angra do Heroísmo.

Drouet, M. H. (1866). Catalogue de la flore des îles Açores précédé de l'itinéraire d'un voyage dans cet archipel. Mémoires de la Société académique de l'Aube, 30 , 81-233.

Engler, R. Guisan, A., \& Rechsteiner, L. (2004). An improved approach for predicting the distribution of rare and endangered species from occurrence and pseudo-absence data. Journal of Applied Ecology, 41, 263-274.

Facon, B., Genton, B. J., Shykoff, J., Jarne, P., Estoup, A., \& David, P. (2006). A general eco-evolutionary framework for understanding bioinvasions. Trends in Ecology E Evolution, 21, 130-135. 
Ferrier, S. \& Watson, G. (1997). An evaluation of the effectiveness of environmental surrogates and modelling techniques in predicting the distribution of biological diversity. Armidale, NSW: Environment Australia.

Fielding, A. H., \& Bell, J. F. (1997). A review of methods for the assessment of prediction errors in conservation presence/absence models. Environmental Conservation, 24, 38-49.

Gangoso, L., Donázar, J., Scholz, S., Palacios, C., \& Hiraldo, F. (2006). Contradiction in conservation of island ecosystems: Plants, introduced herbivores and avian scavengers in the Canary Islands. Biodiversity and Conservation, 15 2231-2248.

Gleadow, R. M., \& Ashton, D. H. (1981). Invasion by Pittosporum undulatum of the forests of Central Victoria. I Invasion patterns and plant morphology. Australian Journal of Botany, 29, 705-720.

Goodland, T., \& Healey, J. R. (1996). The invasion of Jamaican montane rainforests by the Australian tree Pittosporum undulatum. Bangor: School of Agricultural and Forest Sciences, University of Wales.

Hartley, S., Harris, R., \& Lester, P. J. (2006). Quantifying uncertainty in the potential distribution of an invasive species: Climate and the Argentine ant. Ecology Letters, 9, 1068-1079.

Hastings, A., Cuddington, K., Davies, K. F., Dugaw, C. J., Elmendorf, S., \& Freestone A., et al. (2005). The spatial spread of invasions: new developments in theory and evidence. Ecology Letters, 8, 91-101.

Hirzel, A. H., Hausser, J., Chessel, D., \& Perrin, N. (2002). Ecological-niche factor analysis: How to compute habitat-suitability maps without absence data? Ecology, 83, 2027-2036.

Hirzel, A. H., Hausser, J., \& Perrin, N. (2004). Biomapper 3.0. Laboratory for Conservation Biology. Lausanne: University of Lausanne.

Hortal, J., Jiménez-Valverde, A., Gómez, J. F., Lobo, J. M., \& Baselga, A. (2008). Historical bias in biodiversity inventories affects the observed realized niche of the species. Oikos, 117, 847-858.

Hortal, J., Lobo, J. M., \& Jiménez-Valverde, A. (2007). Limitations of biodiversity databases: Case study on seed-plant diversity in Tenerife (Canary Islands). Conservation Biology, 21, 853-863.

Hortal, J., Lobo, J. M., \& Martín-Piera, F. (2001). Forecasting insect species richness scores in poorly surveyed territories: The case of the Portuguese dung beetles (Col. Scarabaeinae). Biodiversity and Conservation, 10, 1343-1367.

Jiménez-Valverde, A., \& Lobo, J. M. (2006). The ghost of unbalanced species distribution data in geographic model predictions. Diversity and Distributions, 12, 521-524.

Jiménez-Valverde, A., Lobo, J. M., \& Hortal, J. (2008). Not as good as they seem: The importance of concepts in species distribution modelling. Diversity and Distributions, 14, 885-890.

Jiménez-Valverde, A., Ortuño, V. M., \& Lobo, J. M. (2007). Exploring the distribution of Sterocorax Ortuño, 1990 (Coleoptera, Carabidae) species in the Iberian Peninsula. Journal of Biogeography, 34, 1426-1438.

Kearney, M. (2006). Habitat, environment and niche: What are we modelling? Oikos, 115, 186-191.

Kingston, N., \& Waldren, S. (2005). A conservation appraisal of the rare and endemic vascular plants of Pitcairn Island. Biodiversity and Conservation, 14, 781-800.

Lake, J. C., \& Leishman, M. R. (2004). Invasion success of exotic plants in natura ecosystems: The role of disturbance, plant attributes and freedom from herbivores. Biological Conservation, 117, 215-226.

Liu, C., Berry, P. M. Dawson, T. P. \& Pearson, R. G. (2005). Selecting thresholds of occurrence in the prediction of species distributions. Ecography, 28, 385-393.

Lobo, J. M. (2008). More complex distribution models or more representative data?. Biodiversity Informatics, 5, 14-19.

Lobo, J. M., Baselga, A., Hortal, J., Jiménez-Valverde, A., \& Gómez, J. F. (2007). How does the knowledge about the spatial distribution of Iberian dung beetle species accumulate over time?. Diversity and Distributions, 13, 772-780.

Lobo, J. M., Jimenez-Valverde, A., \& Real, R. (2008). AUC: A misleading measure of the performance of predictive distribution models. Global Ecology and Biogeography, 17, 145-151.

Lobo, J.M., Jiménez-Valverde, A., \& Hortal, J. (2010). The uncertain nature of absences and their importance in species distribution modelling. Ecography, $33,103-114$

Lobo, J. M., Verdú, J. R., \& Numa, C. (2006). Environmental and geographical factors affecting the Iberian distribution of flightless Jekelius species (Coleoptera: Geotrupidae). Diversity and Distributions, 12, 179-188.

Machado, F. (1946). Génese de alguns solos dos Açores. Boletim da Comissão Reguladora dos Cereais do Arquipélago dos Açores, 3, 1-8.

Mackey, B. G., \& Lindenmayer, D. B. (2001). Towards a hierarchical framework for modelling the spatial distribution of animals. Journal of Biogeography, 28, 1147-1166.

Maes, D., Titeux, N., Hortal, J., Anselin, A., Decleer, K., De Knijf, G., et al. (2010) Predicted insect diversity declines under climate change in an already impoverished region. Journal of Insect Conservation, in press, doi:10.1007/ s10841-010-9277-3.

Manders, P. T., \& Richardson, D. M. (1992). Colonization of Cape fynbos communities by forest species. Forest Ecology and Management, 48, 277-293.

Martins, A. M.F. (1993). The Azores - Westernmost Europe: Where evolution can be caught red-handed. Boletim do Museu Municipal do Funchal, Suppl. 2, $181-198$

Mau-Crimmins, T. M., Schussman, H. R., \& Geiger, E. L. (2006). Can the invaded range of a species be predicted sufficiently using only native-range data? Lehmann lovegrass (Eragrostis lehmanniana) in the southwestern United States. Ecological Modelling, 193, 736-746.
McCullagh, P., \& Nelder, J. A. (1989). Generalized linear models (2nd ed.). London: Chapman \& Hall.

Ogden, J., Deng, Y., Boswijk, G., \& Sandiford, A. (2003). Vegetation changes since early Maori fires in Waipoua Forest, Northern New Zealand. Journal of Archaeological Science, 30, 753-767.

Olden, J. D., Jackson, D. A., \& Peres-Neto, P. R. (2002). Predictive models of fish species distributions: A note on proper validation and chance predictions. Transactions of the American Fisheries Society, 131, 329-336.

Olesen, J. M., Eskildsen, L. I., \& Venkatasamy, S. (2002). Invasion of pollination networks on oceanic islands: Importance of invader complexes and endemic super generalists. Diversity and Distributions, 8, 181-192.

Palhinha, R. T. (1944). Plantas vasculares da ilha Graciosa (Açores). Açoreana, 3 , $163-188$.

Palhinha, R.T., Cunha, A.G., \& Sobrinho, L.G. (1942). Algumas observaçõe ecológicas sobre o Arquipélago Açoriano. In I Congresso Nacional de Ciências Naturais (pp. 197-205).

Parker, I. M., Simberloff, D., Lonsdale, W. M., Goodell, K., Wonham, M., \& Kareiva, P. M., et al. (1999). Impact: Toward a framework for understanding the ecological effects of invaders. Biological Invasions, 1, 3-19.

Pearce, J., \& Ferrier, S. (2000). An evaluation of alternative algorithm for fitting species distribution models using logistic regression. Ecological Modelling, 128 127-147.

Peterson, A. T. (2005). Predicting potential geographic distributions of invading species. Current Science, 89, 9.

R Development Core Team, A. T. (2004). R: A language and environment for statistical computing Vienna, Austria: R Foundation for Statistical Computing

Ramos, J. A. (1995). The diet of the Azores bullfinch and floristic variation within its range. Conservation Biology, 71, 237-249.

Ramos, J. A. (1996). Introduction of exotic tree species as a threat to the Azores bullfinch population. Journal of Applied Ecology, 33, 710-722.

Ricardo, R. P., Madeira, M. A.V., Medina, J. M.B., Marques, N. M., \& Furtado, A. F.A. S (1977). Esboço pedológico da Ilha de São Miguel (Açores). Anais do Instituto Superior de Agronomia, 37, 275-385.

Rose, S. (1997a). Integrating management of Pittosporum undulatum with other environmental weeds in Sidney's urban bushland. Pacific Conservation Biology, $3,350-365$.

Rose, S. (1997b). Influence of suburban edges on invasion of Pittosporum undulatum into the bushland of northern Sydney, Australia. Australian Journa of Ecology, 22, 89-99.

Rose, S., \& Fairweather, P. G. (1997). Changes in floristic composition of urban bushland invaded by Pittosporum undulatum in Northern Sydney, Australia. Australian Journal of Botany, 45, 123-149.

Rouget, M., Richardson, D. M., Cowling, R. M., Lloyd, J. W., \& Lombard, A. T. (2003) Current patterns of habitat transformation and future threats to biodiversity in terrestrial ecosystems of the Cape Floristic Region, South Africa. Biological Conservation, 112, 63-85.

Sanford, N. L., Harrington, R. A., \& Fownes, J. H. (2003). Survival and growth of native and alien woody seedlings in open and understory environments. Forest Ecology and Management, 183, 377-385

Schaefer, H. (2003). Chorology and diversity of the Azorean flora. Dissertationes Botanicae 374. J. Cramer, Stuttgart, 130 pp.+ CD rom (580 pp.).

Shiferaw, H., Teketay, D., Nemomissa, S., \& Assefa, F. (2004). Some biological characteristics that foster the invasion of Prosopis juliflora (Sw.) DC. at Middle Awash Rift Valley Area, north-eastern Ethiopia. Journal of Arid Environments, $58,135-154$.

Shigesada, N., \& Kawasaki, K. (1997). Biological invasions: Theory and practice. Oxford: Oxford University Press.

Silva, L. (2001). Plantas vasculares invasoras no arquipélago dos Açores. Ph.D. Thesis, Universidade dos Açores, Ponta Delgada.

Silva, L., Ojeda Land, E., \& Rodríguez Luengo, J.L. (2008). Invasive terrestrial flora and fauna of Macaronesia. TOP 100 in Azores, Madeira and Canaries. Ponta Delgada: ARENA.

Silva, L., \& Smith, C. (2004). A characterization of the non-indigenous flora of the Azores Archipelago. Biological Invasions, 6, 193-204.

Silva, L., \& Smith, C. (2006). A quantitative approach to the study of nonindigenous plants: An example from the Azores Archipelago. Biodiversity and Conservation, 15, 1661-1679.

Silva, L., Smith, C.W., \& Tavares, J. (1999). Essays for the control of Clethra arborea and Pittosporum undulatum. In Actas do I Encontro Invasoras Lenhosas, 16-18 de Novembro de 1999 (pp. 143-148). Gerês: Sociedade Portuguesa de Ciências Florestais, ADERE.

Silva, L., Smith, C. W. \& Tavares, J. (2000). Biogeography of Azorean plant invaders. Arquipélago - Ciências Biológicas e Marinhas, Sup. 2 - Part, A1, 19-27.

Simberloff, D. (1995). Why do introduced species appear to devastate islands more than mainland areas?. Pacific Science, 49, 87-97.

Simberloff, D. (2004). Community ecology: Is it time to move on?. American Naturalist, 163, 787-799.

Sjögren, E. (1973). Recent changes in the vascular flora and vegetation of the Azores Islands. Memórias da Sociedade Broteriana, 22, 1-113.

Soberón, J. (2007). Grinnellian and Eltonian niches and geographic distributions of species. Ecology Letters, 10, 1115-1123.

Soberón, J., \& Nakamura, M. (2009). Niches and distributional areas: Concepts, methods, and assumptions. Proceedings of the National Academy of Sciences USA, 106, 19644-19650.

Soberón, J., \& Peterson, A. T. (2005). Interpretation of models of fundamental ecological niches and species' distribution areas. Biodiversity Informatics, 2, 1-10. 
SRAF. (2007). PRORURAL. Programa de Desenvolvimento Rural da Região Autónoma dos Açores 2007-2013. Secretaria Regional da Agricultura e Florestas, Região Autónoma dos Açores, Portugal, Ponta Delgada.

StatSoft Inc, M. (2003). STATISTICA (data analysis software system), version 6.1. Tulsa, OK: StatSoft, Inc.

Swets, J. A. (1988). Measuring the accurracy of diagnostic systems. Science, 240, 1285-1293.

Thomaes, A., Kervyn, T., \& Maes, D. (2008). Applying species distribution modelling for the conservation of the threatened saproxylic Stag Beetle (Lucanus cervus). Biological Conservation, 141, 1400-1410.

Trelease, W. (1897). Botanical observations on the Azores. Annual Report of the Missouri Botanical Garden, 8, 77-220.
US Forest Service. (2007-2008). Pacific Island Ecosystems at Risk (PIER). Online resource at 〈http://www.hear.org/pier/〉 [accessed 29 September 2008]. US Forest Service, Department of Agriculture.

Václavík, T., \& Meentemeyer, R. K. (2009). Invasive species distribution modeling (iSDM): Are absence data and dispersal constraints needed to predict actual distributions? Ecological Modelling, 220, 3248-3258.

Weber, E. (2003). Invasive plants of the world. Wallingford, UK: CABI Publishing, $\mathrm{CAB}$ International.

Williamson, M. (1996). Biological invasions. London: Chapman \& Hall.

Zaniewski, A. E., Lehmann, A., \& Overton, J. M. (2002). Predicting species spatial distributions using presence-only data: A case study of native New Zealand ferns. Ecological Modelling, 157, 261-280. 


\section{ELECTRONIC SUPPLEMENTARY MATERIAL}

Figure S1.- Current distribution of Pittosporum undulatum in São Miguel Island. Colours are equivalent to the greyscale in Figure 2: blue - forest patches where the species appears as part of formations dominated by other species; green - forest patches where the species is dominant; and red - patches where $P$. undulatum is the unique forest species.

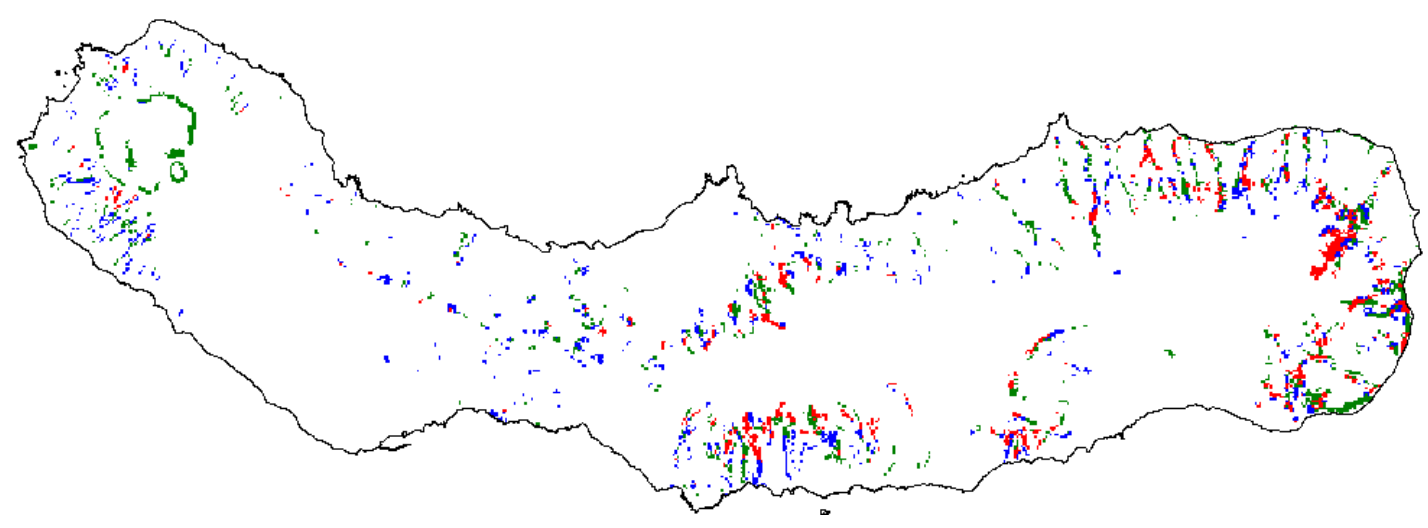


Appendix S2.- Results of the PCA analysis carried out with the 84 climate variables.

Table S2.1- Results from the PCA analysis. CF1 to 4 are the resulting climate factors. Variable codes as in text; scores are for monthly values (numbers from 01 to 12 indicate the month from January to December).

\begin{tabular}{lcccc}
\hline & CF1 & CF2 & CF3 & CF4 \\
\hline Eigenvalue & 58.89 & 15.02 & 4.61 & 3.03 \\
\% Total & 70.11 & 17.88 & 5.49 & 3.60 \\
Cumulative Eigenvalue & 58.89 & 73.92 & 78.53 & 81.55 \\
Cumulative \% & 70.11 & 88.00 & 93.49 & 97.09 \\
\hline & & & & \\
\hline Factor loadings & $\mathbf{C F 1}$ & $\mathbf{C F 2}$ & $\mathbf{C F 3}$ & $\mathbf{C F 4}$ \\
\hline RAIN01 & $\mathbf{0 . 9 1 6}$ & -0.102 & -0.146 & -0.076 \\
RAIN02 & $\mathbf{0 . 9 1 3}$ & -0.105 & -0.147 & -0.074 \\
RAIN03 & $\mathbf{0 . 9 2 8}$ & -0.085 & -0.149 & -0.083 \\
RAIN04 & $\mathbf{0 . 9 3 2}$ & -0.069 & -0.151 & -0.086 \\
RAIN05 & $\mathbf{0 . 9 3 6}$ & -0.068 & -0.151 & -0.086 \\
RAIN06 & $\mathbf{0 . 9 3 4}$ & -0.054 & -0.154 & -0.088 \\
RAIN07 & $\mathbf{0 . 9 2 7}$ & -0.053 & -0.161 & -0.094 \\
RAIN08 & $\mathbf{0 . 9 3 5}$ & -0.083 & -0.165 & -0.102 \\
RAIN09 & $\mathbf{0 . 9 3 9}$ & -0.086 & -0.157 & -0.096 \\
RAIN10 & $\mathbf{0 . 9 3 5}$ & -0.084 & -0.153 & -0.091 \\
RAIN11 & $\mathbf{0 . 9 2 9}$ & -0.113 & -0.153 & -0.097 \\
RAIN12 & $\mathbf{0 . 9 2 1}$ & -0.111 & -0.150 & -0.085 \\
TMAX01 & $\mathbf{- 0 . 9 0 8}$ & 0.113 & 0.359 & 0.115 \\
TMAX02 & $\mathbf{- 0 . 9 1 0}$ & 0.111 & 0.357 & 0.114 \\
TMAX03 & $\mathbf{- 0 . 9 0 7}$ & 0.119 & 0.362 & 0.114 \\
TMAX04 & $\mathbf{- 0 . 9 0 4}$ & 0.133 & 0.367 & 0.115 \\
TMAX05 & $\mathbf{- 0 . 9 0 0}$ & 0.130 & 0.375 & 0.119 \\
TMAX06 & $\mathbf{- 0 . 8 9 4}$ & 0.142 & 0.383 & 0.120 \\
TMAX07 & $\mathbf{- 0 . 8 8 6}$ & 0.153 & 0.391 & 0.122 \\
TMAX08 & $\mathbf{- 0 . 8 9 1}$ & 0.140 & 0.388 & 0.122 \\
TMAX09 & $\mathbf{- 0 . 8 9 6}$ & 0.132 & 0.384 & 0.118 \\
TMAX10 & $\mathbf{- 0 . 8 9 5}$ & 0.139 & 0.383 & 0.118 \\
TMAX11 & $\mathbf{- 0 . 9 0 4}$ & 0.124 & 0.367 & 0.112 \\
TMAX12 & $\mathbf{- 0 . 9 1 5}$ & 0.110 & 0.343 & 0.111 \\
TMIN01 & & & & \\
TMIN02 & $\mathbf{- 0 . 9 0 8}$ & 0.111 & 0.361 & 0.112 \\
TMIN03 & $\mathbf{- 0 . 9 1 7}$ & 0.112 & 0.340 & 0.114 \\
TMIN04 & 0.110 & 0.339 & 0.112 \\
TMIN05 & $\mathbf{- 0 . 9 1 4}$ & 0.116 & 0.343 & 0.113 \\
TMIN06 & $\mathbf{- 0 . 9 1 2}$ & 0.128 & 0.347 & 0.114 \\
TMIN07 & $\mathbf{- 0 . 9 1 0}$ & 0.126 & 0.352 & 0.117 \\
TMIN08 & $\mathbf{- 0 . 9 0 4}$ & 0.137 & 0.361 & 0.117 \\
TMIN09 & $\mathbf{- 0 . 8 9 9}$ & 0.146 & 0.369 & 0.121 \\
TMIN10 & $\mathbf{- 0 . 9 0 1}$ & 0.136 & 0.370 & 0.119 \\
TMIN11 & $\mathbf{0 . 9 0 5}$ & 0.129 & 0.365 & 0.116 \\
TMIN12 & 0.134 & 0.361 & 0.116 \\
\hline COOH.) & 0.122 & 0.349 & 0.111 \\
\hline
\end{tabular}

(Cont.) 
Table S2.1 (Cont.)

\begin{tabular}{|c|c|c|c|c|}
\hline Factor loadings & CF1 & CF2 & CF3 & CF4 \\
\hline ET001 & -0.400 & 0.838 & 0.341 & 0.047 \\
\hline ET002 & -0.396 & 0.832 & 0.316 & 0.186 \\
\hline ET003 & -0.351 & 0.780 & 0.279 & 0.415 \\
\hline ET004 & -0.390 & 0.629 & 0.281 & 0.597 \\
\hline ET005 & -0.399 & 0.447 & 0.295 & 0.738 \\
\hline ET006 & -0.411 & 0.350 & 0.288 & 0.782 \\
\hline ET007 & -0.381 & 0.412 & 0.265 & 0.778 \\
\hline ET008 & -0.293 & 0.609 & 0.197 & 0.705 \\
\hline ET009 & -0.273 & 0.773 & 0.195 & 0.526 \\
\hline ET010 & -0.306 & 0.873 & 0.241 & 0.265 \\
\hline ET011 & -0.351 & 0.881 & 0.279 & 0.071 \\
\hline ET012 & -0.403 & 0.842 & 0.333 & 0.005 \\
\hline RS01 & 0.040 & 0.989 & -0.006 & 0.123 \\
\hline RS02 & 0.034 & 0.961 & 0.001 & 0.265 \\
\hline RS03 & 0.025 & 0.870 & -0.011 & 0.484 \\
\hline RS04 & -0.015 & 0.700 & 0.024 & 0.705 \\
\hline RS05 & -0.071 & 0.479 & 0.063 & 0.868 \\
\hline RS06 & -0.100 & 0.347 & 0.064 & 0.922 \\
\hline RS07 & -0.115 & 0.413 & 0.087 & 0.891 \\
\hline RS08 & -0.060 & 0.629 & 0.047 & 0.768 \\
\hline RS09 & -0.012 & 0.813 & 0.019 & 0.571 \\
\hline RS10 & 0.021 & 0.938 & 0.014 & 0.332 \\
\hline RS11 & 0.035 & 0.983 & -0.013 & 0.165 \\
\hline RS12 & 0.041 & 0.993 & -0.006 & 0.083 \\
\hline RHMAX01 & 0.519 & -0.068 & -0.833 & -0.112 \\
\hline RHMAX02 & 0.505 & -0.065 & -0.839 & -0.103 \\
\hline RHMAX03 & 0.528 & -0.100 & -0.831 & -0.108 \\
\hline RHMAX04 & 0.498 & -0.160 & -0.839 & -0.101 \\
\hline RHMAX05 & 0.484 & -0.142 & -0.850 & -0.118 \\
\hline RHMAX06 & 0.477 & -0.176 & -0.847 & -0.111 \\
\hline RHMAX07 & 0.438 & -0.206 & -0.846 & -0.111 \\
\hline RHMAX08 & 0.467 & -0.153 & -0.855 & -0.113 \\
\hline RHMAX09 & 0.514 & -0.150 & -0.834 & -0.110 \\
\hline RHMAX10 & 0.501 & -0.168 & -0.835 & -0.108 \\
\hline RHMAX11 & 0.541 & -0.130 & -0.813 & -0.097 \\
\hline RHMAX12 & 0.535 & -0.070 & -0.824 & -0.104 \\
\hline RHMIN01 & 0.789 & -0.120 & -0.541 & -0.138 \\
\hline RHMIN02 & 0.811 & -0.114 & -0.516 & -0.134 \\
\hline RHMIN03 & 0.792 & -0.137 & -0.539 & -0.136 \\
\hline RHMIN04 & 0.824 & -0.164 & -0.491 & -0.137 \\
\hline RHMIN05 & 0.804 & -0.160 & -0.515 & -0.145 \\
\hline RHMIN06 & 0.803 & -0.183 & -0.508 & -0.145 \\
\hline RHMIN07 & 0.816 & -0.194 & -0.478 & -0.147 \\
\hline RHMIN08 & 0.832 & -0.170 & -0.470 & -0.145 \\
\hline RHMIN09 & 0.829 & -0.159 & -0.485 & -0.140 \\
\hline RHMIN10 & 0.820 & -0.171 & -0.493 & -0.140 \\
\hline RHMIN11 & 0.806 & -0.147 & -0.520 & -0.130 \\
\hline RHMIN12 & 0.804 & -0.114 & -0.527 & -0.130 \\
\hline Expl.Var & 42.54 & 14.67 & 15.91 & 8.24 \\
\hline Prp.Totl & 0.506 & 0.175 & 0.189 & 0.098 \\
\hline
\end{tabular}


Figure S2.2-Spatial distribution of the scores for the four Climate Factors.
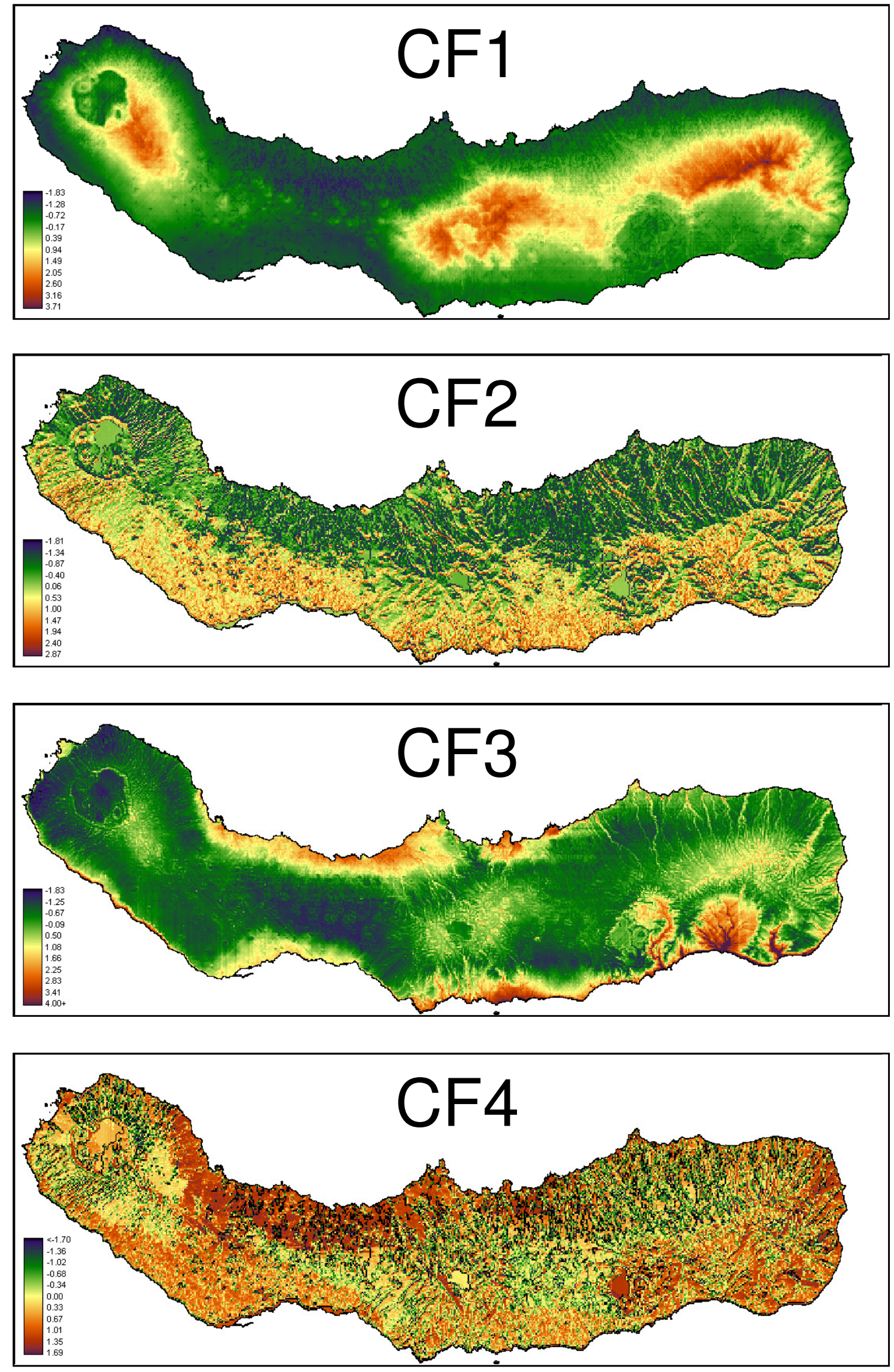
Appendix S3.- Geomorphological and climatic differences between the areas predicted to be suitable or unsuitable for the invasion of Pittosporum undulatum according to our analyses.

Table S3.1- Results of the Mann-Whitney U tests comparing the geomorphological and climatic conditions of the areas predicted to be suitable or unsuitable for Pittosporum undulatum in our analyses. Variable codes as in text; scores are for monthly values (numbers from 01 to 12 indicate the month from January to December). Aspect is calculated as northing (i.e., degrees from the North).

\begin{tabular}{|c|c|c|c|c|c|c|c|c|c|c|c|c|c|c|c|c|c|}
\hline & \multicolumn{3}{|c|}{ Mann-Whitney U Results } & \multicolumn{7}{|c|}{ Predicted suitable } & \multicolumn{7}{|c|}{ Predicted unsuitable } \\
\hline & U & Z Adj. & p-level & Mean & Median & Min & Max & Lower & Upper & Std.Dev. & Mean & Median & Min & Max & Lower & Upper & Std.Dev. \\
\hline Altitude & 18731 & -32.91 & $<0.0001$ & 246.7 & 240.0 & 1.0 & 650.0 & 168.0 & 320.0 & 120.8 & 601.6 & 590.0 & 420.0 & 788.0 & 560.0 & 632.0 & 67.1 \\
\hline Aspect & 1588242 & 1.22 & 0.224 & 57.5 & 49.0 & 0.0 & 180.0 & 22.6 & 90.0 & 44.6 & 52.4 & 47.9 & 0.0 & 180.0 & 25.6 & 81.5 & 36.5 \\
\hline Slope & 1526123 & 2.47 & 0.014 & 12.6 & 10.0 & 0.0 & 64.1 & 6.0 & 16.5 & 9.6 & 10.8 & 9.0 & 0.0 & 36.4 & 6.1 & 12.9 & 7.2 \\
\hline CF1 & 36373 & -32.55 & $<0.0001$ & -0.6 & -0.7 & -1.8 & 1.6 & -1.0 & -0.2 & 0.6 & 1.3 & 1.3 & 0.3 & 2.3 & 1.0 & 1.6 & 0.4 \\
\hline CF2 & 1363130 & 5.76 & $<0.0001$ & -0.4 & -0.5 & -1.8 & 2.8 & -1.1 & 0.0 & 0.8 & -0.6 & -0.9 & -1.8 & 2.1 & -1.3 & -0.1 & 0.9 \\
\hline CF3 & 825424 & -16.62 & $<0.0001$ & -0.5 & -0.7 & -1.8 & 3.1 & -1.0 & -0.2 & 0.7 & -0.1 & -0.2 & -0.8 & 1.4 & -0.4 & 0.1 & 0.3 \\
\hline CF4 & 1078655 & 11.50 & $<0.0001$ & -0.1 & 0.2 & -2.8 & 1.6 & -0.8 & 0.7 & 1.0 & -0.7 & -0.7 & -2.6 & 1.5 & -1.6 & 0.1 & 1.0 \\
\hline CF5 & 882062 & 15.47 & $<0.0001$ & 0.0 & -0.1 & -2.7 & 4.1 & -0.7 & 0.5 & 1.1 & -0.8 & -1.0 & -2.6 & 1.6 & -1.5 & -0.2 & 0.9 \\
\hline RAIN_01 & 215461.5 & -28.94 & $<0.0001$ & 178.2 & 163.4 & 118.1 & 360.6 & 128.4 & 219.3 & 55.6 & 284.3 & 284.4 & 214.3 & 368.7 & 264.2 & 301.1 & 29.8 \\
\hline RAIN_02 & 194680.5 & -29.36 & $<0.0001$ & 136.5 & 125.4 & 90.1 & 275.8 & 98.0 & 167.9 & 42.8 & 223.3 & 223.8 & 163.1 & 280.1 & 207.7 & 240.9 & 25.5 \\
\hline RAIN_03 & 153905.0 & -30.18 & $<0.0001$ & 139.2 & 127.4 & 96.3 & 263.9 & 102.8 & 171.5 & 40.4 & 227.4 & 227.3 & 166.1 & 280.3 & 209.3 & 247.5 & 25.2 \\
\hline RAIN_04 & 103573.0 & -31.20 & $<0.0001$ & 103.2 & 93.1 & 72.4 & 196.4 & 77.1 & 126.8 & 30.1 & 173.9 & 173.8 & 131.9 & 203.9 & 164.7 & 186.8 & 15.5 \\
\hline RAIN_05 & 124224.0 & -30.79 & $<0.0001$ & 87.9 & 77.8 & 62.6 & 168.5 & 65.8 & 108.8 & 25.2 & 144.7 & 143.0 & 114.5 & 176.4 & 132.0 & 158.6 & 15.6 \\
\hline RAIN_06 & 96885.5 & -31.34 & $<0.0001$ & 55.1 & 48.2 & 39.1 & 105.4 & 40.8 & 69.4 & 16.6 & 94.9 & 96.3 & 72.1 & 111.4 & 86.6 & 103.7 & 9.8 \\
\hline RAIN_07 & 98714.0 & -31.31 & $<0.0001$ & 42.5 & 36.6 & 29.6 & 85.0 & 30.6 & 54.5 & 13.7 & 75.8 & 78.1 & 56.9 & 89.8 & 68.3 & 82.9 & 8.1 \\
\hline RAIN_08 & 96492.5 & -31.35 & $<0.0001$ & 65.0 & 57 & 45.0 & 131.0 & 46.9 & 82.7 & 20.4 & 114.6 & 118.0 & 87.0 & 136.7 & 102.6 & 125.4 & 12.5 \\
\hline RAIN_09 & 85517.5 & -31.57 & $<0.0001$ & 139.8 & 124 & 94.4 & 274.2 & 100.0 & 178.7 & 44.3 & 246.3 & 250.4 & 184.2 & 303.5 & 222.8 & 268.3 & 26.4 \\
\hline RAIN_10 & 93689.5 & -31.40 & $<0.0001$ & 147.9 & 131.6 & 99.4 & 295.3 & 106.1 & 187.1 & 47.4 & 260.3 & 259.5 & 197.5 & 315.1 & 242.2 & 282.3 & 25.9 \\
\hline RAIN_11 & 97390.5 & -31.32 & $<0.0001$ & 193.8 & 176.9 & 128.9 & 368.7 & 140.9 & 240.4 & 59.5 & 334.4 & 335.9 & 256.6 & 398.6 & 314.8 & 360.1 & 31.1 \\
\hline RAIN_12 & 171745.0 & -29.82 & $<0.0001$ & 179.8 & 166 & 118.3 & 357.4 & 129.5 & 221.6 & 55.7 & 295.0 & 295.3 & 220.8 & 371.2 & 273.8 & 316.7 & 31.2 \\
\hline
\end{tabular}


Table S3.1 (Cont.)

\begin{tabular}{|c|c|c|c|c|c|c|c|c|c|c|c|c|c|c|c|c|c|}
\hline & \multicolumn{3}{|c|}{ Mann-Whitney U Results } & \multicolumn{3}{|c|}{ Predicted suitable } & \multirow[b]{2}{*}{ Max } & \multirow[b]{2}{*}{ Lower } & \multirow[b]{2}{*}{ Upper } & \multirow[b]{2}{*}{ Std.Dev. } & \multicolumn{3}{|c|}{ Predicted unsuitable } & \multirow[b]{2}{*}{ Max } & \multirow[b]{2}{*}{ Lower } & \multirow[b]{2}{*}{ Upper } & \multirow[b]{2}{*}{ Std.Dev. } \\
\hline & $U$ & Z Adj. & p-level & Mean & Median & Min & & & & & Mean & Median & Min & & & & \\
\hline TMAX_01 & 20481.00 & 32.88 & $<0.0001$ & 15.0 & 15.1 & 12.3 & 17.6 & 14.4 & 15.7 & 1.0 & 12.3 & 12.5 & 11.0 & 13.4 & 12.0 & 12.7 & 0.5 \\
\hline TMAX_02 & 19449.00 & 32.90 & $<0.0001$ & 14.7 & 14.8 & 11.8 & 17.3 & 14.0 & 15.5 & 1.0 & 12.0 & 12.0 & 10.7 & 13.2 & 11.6 & 12.3 & 0.5 \\
\hline TMAX_03 & 18556.00 & 32.92 & $<0.0001$ & 15.1 & 15.2 & 12.4 & 17.8 & 14.4 & 15.9 & 1.0 & 12.4 & 12.5 & 11.0 & 13.6 & 12.1 & 12.8 & 0.5 \\
\hline TMAX_04 & 18115.50 & 32.93 & $<0.0001$ & 15.6 & 15.7 & 12.8 & 18.1 & 14.9 & 16.3 & 1.0 & 12.9 & 13.0 & 11.6 & 13.9 & 12.5 & 13.2 & 0.5 \\
\hline TMAX_05 & 19476.00 & 32.91 & $<0.0001$ & 17.4 & 17.4 & 14.5 & 19.9 & 16.7 & 18.1 & 1.0 & 14.7 & 14.8 & 13.4 & 15.8 & 14.4 & 15.0 & 0.5 \\
\hline TMAX_06 & 16307.00 & 32.97 & $<0.0001$ & 19.5 & 19.6 & 16.9 & 22.0 & 18.8 & 20.3 & 1.0 & 16.9 & 17.0 & 15.7 & 17.8 & 16.5 & 17.2 & 0.5 \\
\hline TMAX_07 & 17254.50 & 32.95 & $<0.0001$ & 22.1 & 22.2 & 19.4 & 24.6 & 21.4 & 22.7 & 1.0 & 19.5 & 19.5 & 18.1 & 20.4 & 19.2 & 19.8 & 0.5 \\
\hline TMAX_08 & 21607.00 & 32.86 & $<0.0001$ & 23.4 & 23.5 & 20.5 & 25.9 & 22.7 & 24.1 & 1.0 & 20.8 & 20.9 & 19.5 & 21.8 & 20.5 & 21.1 & 0.5 \\
\hline TMAX_09 & 20494.00 & 32.88 & $<0.0001$ & 22.6 & 22.7 & 19.9 & 25.2 & 21.9 & 23.3 & 1.0 & 19.9 & 20.0 & 18.6 & 21.0 & 19.6 & 20.3 & 0.5 \\
\hline TMAX_10 & 21088.00 & 32.87 & $<0.0001$ & 20.6 & 20.7 & 17.8 & 23.3 & 19.9 & 21.2 & 1.0 & 17.9 & 18.0 & 16.6 & 18.9 & 17.6 & 18.3 & 0.5 \\
\hline TMAX_11 & 18085.00 & 32.93 & $<0.0001$ & 17.7 & 17.8 & 14.9 & 20.4 & 17.1 & 18.5 & 1.0 & 15.0 & 15.1 & 13.8 & 16.0 & 14.7 & 15.4 & 0.5 \\
\hline TMAX_12 & 21723.50 & 32.86 & $<0.0001$ & 16.2 & 16.2 & 13.3 & 18.7 & 15.5 & 16.9 & 1.0 & 13.4 & 13.6 & 12.2 & 14.4 & 13.1 & 13.8 & 0.5 \\
\hline TMIN_01 & 18656.00 & 32.92 & $<0.0001$ & 9.7 & 9.7 & 6.9 & 12.3 & 9.0 & 10.4 & 1.0 & 6.9 & 7.0 & 5.5 & 8.0 & 6.6 & 7.3 & 0.5 \\
\hline TMIN_02 & 20497.50 & 32.88 & $<0.0001$ & 9.1 & 9.1 & 6.1 & 11.5 & 8.4 & 9.8 & 1.0 & 6.2 & 6.3 & 4.7 & 7.4 & 5.9 & 6.6 & 0.6 \\
\hline TMIN_03 & 19309.50 & 32.91 & $<0.0001$ & 9.7 & 9.8 & 6.7 & 12.3 & 9.0 & 10.3 & 1.0 & 6.9 & 7.0 & 5.5 & 8.1 & 6.5 & 7.3 & 0.5 \\
\hline TMIN_04 & 14697.50 & 33.00 & $<0.0001$ & 9.8 & 9.9 & 6.9 & 12.3 & 9.1 & 10.5 & 1.0 & 6.9 & 7.1 & 5.6 & 8.1 & 6.6 & 7.3 & 0.5 \\
\hline TMIN_05 & 16652.00 & 32.96 & $<0.0001$ & 11.2 & 11.3 & 8.4 & 13.8 & 10.6 & 11.9 & 1.0 & 8.4 & 8.5 & 7.0 & 9.5 & 8.1 & 8.8 & 0.5 \\
\hline TMIN_06 & 17460.50 & 32.95 & $<0.0001$ & 13.2 & 13.3 & 10.3 & 15.7 & 12.5 & 13.9 & 1.0 & 10.4 & 10.6 & 9.2 & 11.6 & 10.1 & 10.8 & 0.5 \\
\hline TMIN_07 & 17647.00 & 32.94 & $<0.0001$ & 15.1 & 15.2 & 12.4 & 17.6 & 14.4 & 15.8 & 1.0 & 12.4 & 12.6 & 11.1 & 13.5 & 12.1 & 12.8 & 0.5 \\
\hline TMIN_08 & 18488.50 & 32.92 & $<0.0001$ & 16.3 & 16.3 & 13.6 & 18.8 & 15.6 & 17.0 & 1.0 & 13.6 & 13.7 & 12.3 & 14.5 & 13.3 & 13.9 & 0.5 \\
\hline TMIN_09 & 17695.50 & 32.94 & $<0.0001$ & 15.9 & 16 & 13.0 & 18.6 & 15.2 & 16.7 & 1.0 & 13.2 & 13.3 & 11.9 & 14.3 & 12.9 & 13.6 & 0.5 \\
\hline TMIN_10 & 18112.00 & 32.93 & $<0.0001$ & 14.0 & 14.1 & 11.1 & 16.5 & 13.4 & 14.8 & 1.0 & 11.3 & 11.4 & 9.9 & 12.3 & 10.9 & 11.6 & 0.5 \\
\hline TMIN_11 & 17703.00 & 32.94 & $<0.0001$ & 12.3 & 12.4 & 9.4 & 15.0 & 11.6 & 13.0 & 1.0 & 9.5 & 9.6 & 8.0 & 10.6 & 9.1 & 9.9 & 0.5 \\
\hline TMIN_12 & 19459.50 & 32.90 & $<0.0001$ & 10.7 & 10.8 & 7.9 & 13.2 & 10.0 & 11.4 & 1.0 & 7.9 & 8.0 & 6.6 & 9.0 & 7.5 & 8.3 & 0.5 \\
\hline
\end{tabular}


Table S3.1 (Cont.)

\begin{tabular}{|c|c|c|c|c|c|c|c|c|c|c|c|c|c|c|c|c|c|}
\hline & \multicolumn{3}{|c|}{ Mann-Whitney U Results } & \multicolumn{3}{|c|}{ Predicted suitable } & \multirow[b]{2}{*}{ Max } & \multirow[b]{2}{*}{ Lower } & \multirow[b]{2}{*}{ Upper } & \multirow[b]{2}{*}{ Std.Dev. } & \multicolumn{3}{|c|}{ Predicted unsuitable } & \multirow[b]{2}{*}{ Max } & \multirow[b]{2}{*}{ Lower } & \multirow[b]{2}{*}{ Upper } & \multirow[b]{2}{*}{ Std.Dev. } \\
\hline & $U$ & Z Adj. & p-level & Mean & Median & Min & & & & & Mean & Median & Min & & & & \\
\hline ET0_01 & 609435 & 21.06 & $<0.0001$ & 23.0 & 21.7 & -3.1 & 77.5 & 15.5 & 27.9 & 11.0 & 10.4 & 6.2 & -6.2 & 37.2 & 3.1 & 15.5 & 9.3 \\
\hline ETO_02 & 592347 & 21.38 & $<0.0001$ & 25.0 & 25.2 & -2.8 & 70.0 & 16.8 & 30.8 & 11.1 & 11.3 & 11.2 & -5.6 & 33.6 & 2.8 & 16.8 & 9.3 \\
\hline ETO_03 & 645657 & 20.29 & $<0.0001$ & 32.5 & 34.1 & -3.1 & 71.3 & 21.7 & 43.4 & 14.6 & 15.9 & 18.6 & -6.2 & 37.2 & 3.1 & 27.9 & 12.4 \\
\hline ETO_04 & 523133 & 22.76 & $<0.0001$ & 41.7 & 45.0 & 0.0 & 78.0 & 33.0 & 54.0 & 15.8 & 21.2 & 27.0 & -3.0 & 45.0 & 9.0 & 30.0 & 12.5 \\
\hline ETO_05 & 540867 & 22.40 & $<0.0001$ & 53.4 & 55.8 & 9.3 & 93.0 & 40.3 & 65.1 & 17.6 & 30.9 & 34.1 & 6.2 & 58.9 & 18.6 & 40.3 & 13.4 \\
\hline ETO_06 & 533811 & 22.53 & $<0.0001$ & 58.7 & 63.0 & 15.0 & 99.0 & 45.0 & 72.0 & 18.0 & 35.3 & 36.0 & 12.0 & 66.0 & 21.0 & 45.0 & 13.6 \\
\hline ETO_07 & 566930 & 21.86 & $<0.0001$ & 68.5 & 71.3 & 15.5 & 114.7 & 52.7 & 83.7 & 22.2 & 41.0 & 43.4 & 9.3 & 83.7 & 24.8 & 52.7 & 16.6 \\
\hline ET0_08 & 645155 & 20.27 & $<0.0001$ & 64.6 & 71.3 & 3.1 & 114.7 & 49.6 & 83.7 & 25.7 & 37.0 & 43.4 & -3.1 & 80.6 & 15.5 & 52.7 & 20.9 \\
\hline ETO_09 & 688317 & 19.41 & $<0.0001$ & 47.9 & 54.0 & -6.0 & 99.0 & 33.0 & 63.0 & 22.5 & 24.8 & 30.0 & -12.0 & 60.0 & 3.0 & 42.0 & 19.5 \\
\hline ETO_10 & 727156 & 18.63 & $<0.0001$ & 36.0 & 37.2 & -6.2 & 93.0 & 21.7 & 46.5 & 17.3 & 17.8 & 18.6 & -6.2 & 55.8 & 3.1 & 31.0 & 15.3 \\
\hline ET0_11 & 701850 & 19.16 & $<0.0001$ & 25.1 & 24.0 & -6.0 & 84.0 & 15.0 & 33.0 & 12.7 & 11.9 & 9.0 & -6.0 & 45.0 & 3.0 & 18.0 & 11.3 \\
\hline ETO_12 & 594536 & 21.36 & $<0.0001$ & 23.4 & 21.7 & -3.1 & 80.6 & 15.5 & 27.9 & 11.3 & 10.5 & 6.2 & -6.2 & 40.3 & 3.1 & 15.5 & 9.4 \\
\hline RHMAX_01 & 621130.5 & -20.75 & $<0.0001$ & 97.8 & 98.4 & 89.6 & 100.1 & 96.6 & 99.3 & 1.8 & 99.4 & 99.5 & 97.3 & 100.1 & 99.2 & 99.8 & 0.5 \\
\hline RHMAX_02 & 651350.0 & -20.14 & $<0.0001$ & 97.6 & 98.3 & 89.2 & 99.9 & 96.2 & 99.2 & 1.9 & 99.3 & 99.4 & 97.3 & 99.9 & 99.1 & 99.7 & 0.4 \\
\hline RHMAX_03 & 622684.0 & -20.72 & $<0.0001$ & 97.8 & 98.3 & 90.0 & 100.1 & 96.7 & 99.3 & 1.8 & 99.4 & 99.5 & 97.1 & 100.1 & 99.2 & 99.8 & 0.5 \\
\hline RHMAX_04 & 542155.0 & -22.35 & $<0.0001$ & 98.0 & 98.5 & 90.6 & 100.0 & 97.2 & 99.2 & 1.6 & 99.5 & 99.6 & 96.7 & 100.0 & 99.3 & 99.8 & 0.5 \\
\hline RHMAX_05 & 615727.0 & -20.86 & $<0.0001$ & 98.1 & 98.6 & 90.5 & 100.0 & 97.3 & 99.3 & 1.6 & 99.4 & 99.5 & 97.3 & 100.0 & 99.2 & 99.8 & 0.4 \\
\hline RHMAX_06 & 576617.5 & -21.65 & $<0.0001$ & 98.2 & 98.6 & 91.3 & 99.9 & 97.5 & 99.3 & 1.5 & 99.4 & 99.5 & 96.7 & 99.9 & 99.3 & 99.8 & 0.4 \\
\hline RHMAX_07 & 660486.5 & -19.96 & $<0.0001$ & 98.5 & 98.8 & 92.2 & 100.0 & 97.9 & 99.5 & 1.3 & 99.5 & 99.6 & 96.8 & 100.0 & 99.3 & 99.8 & 0.4 \\
\hline RHMAX_08 & 615900.0 & -20.86 & $<0.0001$ & 98.3 & 98.7 & 91.5 & 100.1 & 97.5 & 99.4 & 1.5 & 99.5 & 99.6 & 97.1 & 100.1 & 99.3 & 99.9 & 0.4 \\
\hline RHMAX_09 & 526070.0 & -22.67 & $<0.0001$ & 98.0 & 98.5 & 90.8 & 100.0 & 97.1 & 99.3 & 1.6 & 99.5 & 99.6 & 96.9 & 100.0 & 99.3 & 99.8 & 0.4 \\
\hline RHMAX_10 & 570308.0 & -21.78 & $<0.0001$ & 98.1 & 98.6 & 90.8 & 100.2 & 97.3 & 99.4 & 1.6 & 99.6 & 99.6 & 97.0 & 100.2 & 99.3 & 99.9 & 0.4 \\
\hline RHMAX_11 & 449437.0 & -24.22 & $<0.0001$ & 97.8 & 98.3 & 89.7 & 99.9 & 96.9 & 99.1 & 1.7 & 99.4 & 99.5 & 96.6 & 99.9 & 99.3 & 99.8 & 0.5 \\
\hline RHMAX_12 & 564903.5 & -21.88 & $<0.0001$ & 97.7 & 98.3 & 89.3 & 100.2 & 96.5 & 99.3 & 1.9 & 99.5 & 99.6 & 97.1 & 100.2 & 99.2 & 99.9 & 0.5 \\
\hline
\end{tabular}


Table S3.1 (Cont.)

\begin{tabular}{|c|c|c|c|c|c|c|c|c|c|c|c|c|c|c|c|c|c|}
\hline & \multicolumn{3}{|c|}{ Mann-Whitney U Results } & \multicolumn{3}{|c|}{ Predicted suitable } & \multirow[b]{2}{*}{ Max } & \multirow[b]{2}{*}{ Lower } & \multirow[b]{2}{*}{ Upper } & \multirow[b]{2}{*}{ Std.Dev. } & \multicolumn{3}{|c|}{ Predicted unsuitable } & \multirow[b]{2}{*}{ Max } & \multirow[b]{2}{*}{ Lower } & \multirow[b]{2}{*}{ Upper } & \multirow[b]{2}{*}{ Std.Dev. } \\
\hline & $U$ & Z Adj. & p-level & Mean & Median & Min & & & & & Mean & Median & Min & & & & \\
\hline RHMIN_01 & 83989 & -31.59 & $<0.0001$ & 87.9 & 87.4 & 77.4 & 99.5 & 84.6 & 91.1 & 4.4 & 97.0 & 96.9 & 93.5 & 99.6 & 96.0 & 98.0 & 1.3 \\
\hline RHMIN_02 & 70410 & -31.86 & $<0.0001$ & 87.0 & 86.6 & 76.4 & 99.1 & 83.5 & 90.3 & 4.5 & 96.7 & 96.6 & 93.3 & 99.5 & 95.8 & 97.8 & 1.4 \\
\hline RHMIN_03 & 73381 & -31.80 & $<0.0001$ & 88.0 & 87.5 & 77.8 & 99.4 & 84.7 & 91.2 & 4.3 & 97.1 & 97.0 & 93.9 & 99.6 & 96.2 & 98.0 & 1.2 \\
\hline RHMIN_04 & 31338 & -32.65 & $<0.0001$ & 86.8 & 86.2 & 76.9 & 98.8 & 83.6 & 89.8 & 4.3 & 97.1 & 97.1 & 93.5 & 99.8 & 96.4 & 98.0 & 1.3 \\
\hline RHMIN_05 & 43089 & -32.41 & $<0.0001$ & 87.5 & 87 & 77.7 & 99.0 & 84.5 & 90.5 & 4.2 & 97.2 & 97.2 & 93.7 & 99.7 & 96.4 & 98.2 & 1.2 \\
\hline RHMIN_06 & 33139 & -32.62 & $<0.0001$ & 87.7 & 87.1 & 78.3 & 98.9 & 84.8 & 90.5 & 4.0 & 97.3 & 97.3 & 93.9 & 99.7 & 96.5 & 98.2 & 1.2 \\
\hline RHMIN_07 & 26628 & -32.75 & $<0.0001$ & 86.9 & 86.5 & 78.2 & 97.8 & 84.2 & 89.6 & 3.9 & 96.8 & 96.7 & 93.0 & 99.8 & 95.8 & 97.8 & 1.5 \\
\hline RHMIN_08 & 31582 & -32.65 & $<0.0001$ & 86.7 & 86.3 & 78.0 & 97.5 & 84.0 & 89.3 & 3.8 & 96.4 & 96.3 & 92.8 & 99.7 & 95.3 & 97.6 & 1.6 \\
\hline RHMIN_09 & 32616 & -32.63 & $<0.0001$ & 87.3 & 86.8 & 78.1 & 98.2 & 84.4 & 90.1 & 4.0 & 96.9 & 97.0 & 93.5 & 99.6 & 96.0 & 97.9 & 1.3 \\
\hline RHMIN_10 & 31976 & -32.64 & $<0.0001$ & 87.4 & 86.9 & 78.1 & 98.7 & 84.4 & 90.3 & 4.0 & 97.1 & 97.1 & 93.8 & 99.7 & 96.4 & 98.0 & 1.2 \\
\hline RHMIN_11 & 45890 & -32.36 & $<0.0001$ & 87.9 & 87.4 & 77.6 & 99.1 & 84.8 & 91.1 & 4.3 & 97.4 & 97.3 & 93.3 & 99.6 & 96.8 & 98.1 & 1.0 \\
\hline RHMIN_12 & 67394 & -31.92 & $<0.0001$ & 87.7 & 87.2 & 77.3 & 99.5 & 84.3 & 91.0 & 4.4 & 97.0 & 97.0 & 94.0 & 99.6 & 96.2 & 98.0 & 1.2 \\
\hline RS_01 & 1440171 & 4.22 & $<0.0001$ & 4.1 & 4.3 & 0.0 & 16.1 & 0.8 & 6.1 & 3.4 & 3.6 & 3.1 & 0.0 & 14.7 & 0.0 & 5.9 & 3.7 \\
\hline RS_02 & 1394352 & 5.14 & $<0.0001$ & 5.6 & 6.2 & 0.0 & 16.7 & 2.1 & 8.2 & 3.8 & 4.6 & 4.8 & 0.0 & 15.7 & 0.1 & 7.7 & 4.1 \\
\hline RS_03 & 1261161 & 7.82 & $<0.0001$ & 7.5 & 8.9 & 0.0 & 15.5 & 4.3 & 10.5 & 4.1 & 5.8 & 6.8 & 0.0 & 14.6 & 1.1 & 9.5 & 4.2 \\
\hline RS_04 & 1034180 & 12.40 & $<0.0001$ & 10.5 & 11.9 & 1.1 & 16.7 & 8.0 & 13.5 & 4.3 & 8.0 & 9.6 & 1.1 & 16.4 & 3.8 & 11.3 & 4.2 \\
\hline RS_05 & 969394 & 13.71 & $<0.0001$ & 12.6 & 13.7 & 3.1 & 18.1 & 10.1 & 15.7 & 4.1 & 9.9 & 10.1 & 3.3 & 18.0 & 6.7 & 12.8 & 3.8 \\
\hline RS_06 & 944588 & 14.21 & $<0.0001$ & 13.1 & 14.1 & 4.1 & 18.6 & 10.2 & 16.2 & 3.9 & 10.3 & 10.1 & 4.1 & 18.6 & 7.4 & 12.9 & 3.6 \\
\hline RS_07 & 910740 & 14.90 & $<0.0001$ & 14.0 & 14.9 & 3.8 & 20.3 & 11.0 & 17.3 & 4.5 & 10.6 & 10.5 & 3.8 & 20.3 & 7.4 & 13.6 & 4.0 \\
\hline RS_08 & 949803 & 14.11 & $<0.0001$ & 12.7 & 14 & 1.6 & 20.0 & 9.8 & 16.4 & 5.0 & 9.4 & 10.5 & 1.7 & 19.8 & 5.1 & 12.7 & 4.6 \\
\hline RS_09 & 1099049 & 11.09 & $<0.0001$ & 9.7 & 11.2 & 0.1 & 18.3 & 6.5 & 13.2 & 4.8 & 7.2 & 8.4 & 0.1 & 17.3 & 2.2 & 11.1 & 4.6 \\
\hline RS_10 & 1336257 & 6.31 & $<0.0001$ & 6.7 & 7.6 & 0.0 & 17.7 & 3.1 & 9.6 & 4.2 & 5.2 & 5.8 & 0.0 & 17.3 & 0.6 & 8.8 & 4.3 \\
\hline RS_11 & 1405722 & 4.91 & $<0.0001$ & 4.7 & 5 & 0.0 & 16.7 & 1.1 & 6.9 & 3.6 & 3.9 & 3.5 & 0.0 & 16.1 & 0.0 & 6.6 & 3.8 \\
\hline RS_12 & 1445826 & 4.11 & $<0.0001$ & 3.9 & 3.9 & 0.0 & 16.3 & 0.6 & 5.7 & 3.3 & 3.4 & 2.6 & 0.0 & 15.5 & 0.0 & 5.6 & 3.6 \\
\hline
\end{tabular}

